\title{
A Hipótese Colonial, um diálogo com Michel Foucault: a modernidade e o Atlântico Negro no centro do debate sobre racismo e sistema penal ${ }^{*}$
}

\author{
The Colonial Hypothesis, a dialogue with \\ Michel Foucault: the modernity and the Black \\ Atlantic in the center of the debate on racism \\ and the penal system
}

Evandro Piza Duarte ${ }^{1}$ Marcos Vinícius Lustosa Queiroz ${ }^{2}$ Pedro Argolo Costa ${ }^{3}$
Recebido em: 18/08/2016. Aprovado em: 22/08/2016.

1 É Mestre em Direito pela Universidade Federal de Santa Catarina UFSC, Doutor em Direito pela Universidade Nacional de Brasília (UnB), Professor de Processo Penal e Criminologia na Universidade de Brasília (UnB), Professor na Cátedra Brasil sobre Relações Raciais (Capes) na Universidade Nacional da Colômbia (2014), Coordenador do Centro de Estudos em Desigualdade e Discriminação da Faculdade de Direito da Universidade de Brasília (CEDD/FD/UnB), integrante do Grupo de Investigación sobre Igualdad Racial, Diferencia Cultural, Conflictos Ambientales y Racismos en las Américas Negras-IDCARÁN da Universidade Nacional da Colômbia, e integrante do Núcleo de Estudos Maré sobre Cultura Jurídica e Atlântico Negro.

2 Mestrando em Direito pela Universidade de Brasília. Integrante do Centro de Estudos em Desigualdade e Discriminação (CEDD-UnB) e do Maré: Núcleo de Estudos em Cultura Jurídica e Atlântico Negro.

3 Bacharel em Direito pela Universidade de Brasília. Integrante do Centro de Estudos em Desigualdade e Discriminação (CEDD-UnB) e do Maré: Núcleo de Estudos em Cultura Jurídica e Atlântico Negro.

\section{Resumo}

O presente texto, ao refletir sobre os limites das narrativas tradicionais e críticas sobre a história do controle social e de seus saberes, debate uma questão: de que modo o controle social numa determinada época estaria vinculado à raça e, especificamente, como ele produziria uma discriminação dos "negros"? Para responder a essa questão se propõe um diálogo com os conceitos de "vida nua" de Giorgio Agamben e o de "dispositivo" de Michel Foucault, revisitando as ideias da "hipótese colonial" na explicação da violência das formas de controle social, especialmente na constituição do racismo. A construção da análise sobre a raça, a partir do conceito de "dispositivo", lança uma alternativa à oposição entre as noções de racismo como prática e como episteme. Ao mesmo tempo dá-se visibilidade na construção do biopoder às práticas e disputas em outras margens da Modernidade. A violência da Conquista passa a ser vista como práxis constitutiva, muito antes do surgimento do signo "raça". No mesmo passo, a disputa no Atlântico Negro, pelo controle das Cidades Negras e das ressignificações políticas e culturais da Diáspora Africana, adquirem uma dimensão estratégica para refletir sobre o surgimento das práticas penais.

Palavras-chave: Criminologia Crítica. Sistema Penal. História. Racismo. Atlântico Negro. Michel Foucault.

\begin{abstract}
By speculating over the limits of traditional and critical narratives on the history of social control, the present text discusses one issue: how would social control in a particular period in time be tied to race and, especifically, how would it produce discrimination towards "black" people? In order to answer to this question, we suggest a dialogue between the Agambenian concept of "bare life" and Foucault's "dispositif". Thenceforth, we also review ideas from the "colonial hypothesis" on the explanation of the violence of social control forms, mainly on the constitution of racism. The construction of the analysis on race, from the concept of "dispositif", casts an alternative to the oposition between the notions of racism as practice and racism as episteme. Meanwhile, on the construction of biopower, visibility is given to practices and disputes on other margins of Modernity. The violence of Conquest is now seen as constitutive praxis, long before the birth of the sign "race". On the same pace, the quarrels on the Black Atlantic over the control of the Black Cities, alongside with the political and cultural resignifications caused by the African Diaspora, acquire a strategical dimension in order to meditate on the appearance of criminal practices.
\end{abstract}

Keywords: Critical Criminology. Criminal Justice System. History. Racism. Black Atlantic. Michel Foucault. 


\section{Introdução}

O debate público sobre o genocídio da juventude negra (e pobre) trouxe para a arena política novamente uma pauta conhecida do movimento negro brasileiro desde, no mínimo, 1978 com o surgimento do Movimento Negro Unificado ${ }^{4}{ }^{5}$ Não são poucas as novas vozes públicas que passam a reconhecer, com diferentes intensidades e perspectivas, o racismo, o preconceito e a discriminação como problemas. No mesmo passo, especialmente a partir da tradução dos textos de Loic Wacquant sobre o sistema penal americano e outras abordagens sobre os imigrantes na Europa, o tema da racialização do sistema penal surge tardiamente para o campo criminológico no Brasil $^{6}$. Nesse cenário, como apontou Felipe Freitas ${ }^{7}$, o racismo institucional e a branquidade ${ }^{8}$ marcaram em muito o silêncio acadêmico sobre o tema.

$4 \quad$ NASCIMENTO, Abdias do; NASCIMENTO, Elisa Larkin. Reflexões sobre o movimento negro no Brasil, 1938-1997. In: HUNTLEY, Lynn; GUIMARÃES, Antônio Sérgio Alfredo. Tirando a máscara: ensaios sobre o racismo no Brasil. São Paulo: Paz e Terra, 2000. p. 203-235.

5 O próprio Movimento Negro Unificado nasce em resposta à discriminação racial sofrida por quatro garotos do time infantil de voleibol do Clube de Regatas Tietê, bem como para denunciar a prisão e a morte de Robison Siveira da Luz, acusado de roubar frutas numa feira. É a partir desses dois fatos que representantes de várias entidades negras convocam homens e mulheres negros a reagir à violência racial a qual eram submetidos. Em resposta a esse chamado, em 07 de julho de 1978, nas escadarias do Teatro Municipal de São Paulo, tem-se o ato histórico de fundação do MNU. CF.: JARDIM, Drielly. MNU: 34 anos de luta contra o preconceito racial. Disponível em: <http://www. palmares.gov.br/?p=21311>. Acesso em: 08 nov. 2016.

6 WACQUANT, Loïc. Crime e castigo nos Estados Unidos: de Nixon a Clinton. Revista de Sociologia e Política. Dossiê Cidadania e Violência. Curitiba, n. 13, p. 39-50, nov. 1999; WACQUANT, Loïc. As prisões da miséria. Rio de Janeiro: J. Zahar, 2001; WACQUANT, Loïc. A cor da justiça: quando gueto e prisão se encontram e se mesclam. In: LINS, Daniel; WACQUANT, Loïc (Org.). Repensar os Estados Unidos. Campinas: Papirus, 2003. p. 159-208. WACQUANT, Loïc. Da escravidão ao encarceramento em massa: repensando a 'questão racial' nos Estados Unidos. In: SADER, Emir (Ed.). Contragolpes. São Paulo: Boitempo, 2006. p. 11-30. WACQUANT, Loïc. Punir os pobres. Rio de Janeiro: Revan, 2007. FREITAS, Felipe da Silva. Novas perguntas para a criminologia brasileira: poder, racismo e direito no centro da roda. In: ENCONTRO DO GRUPO BRASILEIRO DE CRIMINOLOGIA CRÍTICA, 3., 2016, Salvador. Anais... Salvador, 2016.

8 O termo "branquidade" denota a identidade racial branca e seus privilégios, tendo sido adotado como tradução do termo whiteness, empregado na obra: WARE, Vron. Branquidade: identidade branca e multiculturalismo. Rio de Janeiro: Garamond, 2004. Ressalte-se ainda que há controvérsia quanto os usos de "branquidade" e "branquitude", a primeira indicando para alguns autores a identidade ra-
Apesar de inúmeras nuances entre as (os) estudiosas (os), constata-se uma convicção ascendente sobre a continuidade no racismo do controle social no Brasil. O presente texto, ao refletir sobre os limites das narrativas tradicionais e críticas sobre a história do controle social e de seus saberes, debate uma questão: de que modo o controle social numa determinada época estaria vinculado à raça e, especificamente, como ele produziria uma discriminação dos "negros"? Entretanto, não se trata aqui de propor um trabalho de historiador, mas da possibilidade de reler os temas tradicionais dos manuais introdutórios (e da formação profissionalizante que lhe é inerente) sob novo ângulo, adequando a narrativa às novas perspectivas do conhecimento historiográfico e à reflexão do presente, e ao mesmo tempo, deslocar as abordagens que se constituem no espaço da crítica, mas que desprezam ou secundarizam a centralidade sobre o debate quanto ao racismo.

Propõe-se um diálogo com os conceitos de "vida nua" de Giorgio Agamben e de "dispositivo" de Michel Foucault, revisitando as ideias da "hipótese colonial" na explicação da violência das formas de controle social, especialmente na constituição do racismo.Para sustentar a análise, é sugerido o conceito de raça como "dispositivo", lançando uma alternativa entre racismo como prática e como episteme, ao mesmo tempo que se dá visibilidade na construção do biopoder às práticas e disputas em outras margens da Modernidade. A violência da Conquista na Modernidade passa, desse modo, a ser vista como práxis constitutiva, muito antes do surgimento do signo "raça". No mesmo passo, a disputa no Atlântico Negro, pelo controle das Cidades $\mathrm{Ne}$ gras e das ressignificações políticas e culturais da Diáspora Africana, adquirem uma dimensão estratégica para refletir sobre o surgimento das práticas penais.

\section{Os paradigmas em criminologia e o debate sobre a hipótese colonial}

A coleta e a análise de dados no âmbito do sistema de justiça criminal distribuídos por raça/cor ${ }^{9}$ sugerem, inicialmente, a apresentação de como a literatu-

cial branca não questionadora de seus privilégios, ao passo que a segunda diria respeito ao indivíduo branco que questiona suas vantagens raciais. Sobre a controvérsia, cf.: CARDOSO, Lourenço. A Branquitude acrítica revisitada e a Branquidade. Revista da ABPN, Florianópolis, v. 6, n. 13, p. 88-106, mar./jun. 2014.

9 OSÓRIO, Rafael Guerreiro. O sistema classificatório de 'cor ou raça' do IBGE. In: BERNARDINO-COSTA; GAL- 
ra no campo da Criminologia (Sociologia Criminal) ${ }^{10}$ construiu uma "gramática" capaz de apresentar os pontos centrais dessa questão. A propósito, considerando o debate anteriormente proposto por Vera Andrade ${ }^{11}$, Alessandro Baratta ${ }^{12}$ e Stanley Cohen ${ }^{13}$ sobre as mudanças em paradigma em Criminologia e por Greene e Gabbidon ${ }^{14}$ e Duarte ${ }^{15}$ sobre a relação entre Criminologia e racismo, pode-se destacar a existência de três grandes momentos no debate sobre a questão criminal e as relações raciais.

O primeiro momento inicia com o nascimento da Criminologia como ciência (Paradigma Etiológico), na década de 1870 com a Escola Positiva Italiana, e a consolidação do uso de "instituições totais" como estratégia

DINO, Daniela. Levando a raça a sério: ação afirmativa e universidade. Rio de Janeiro: DP\&A, 2004, p. 85-135; PETRUCCELI, José Luis. A cor denominada: estudos sobre a classificação étnico-racial. Rio de Janeiro: DP\&A, 2007.

10 Conforme afirma Baratta: "O objeto da sociologia jurídico-penal corresponde às três categorias de comportamentos objeto da sociologia jurídica em geral. A sociologia jurídico-penal estudará, pois, em primeiro lugar, as ações e os comportamentos normativos que consistem na formação e na aplicação de um sistema penal dado; em segundo lugar, estudará os efeitos do sistema entendido como aspecto 'institucional' da reação ao comportamento desviante e do correspondente controle social. A terceira categoria de ações e comportamentos abrangidos pela sociologia jurídico-penal compreenderá, ao contrário (a) as reações não-institucionais ao comportamento desviante, entendidas como um aspecto integrante do controle social do desvio, em concorrência com as reações institucionais estudadas nos dois primeiros aspectos e (b) em nível de abstração mais elevado, as conexões entre um sistema penal dado e a correspondente estrutura econômico social". Cf.: BARATTA, Alessandro. Criminologia crítica e crítica do direito penal: introdução à sociologia do direito penal. Rio de Janeiro: Revan, 1999. p. 23.

11 ANDRADE, Vera Regina Pereira de. Do paradigma etiológico ao paradigma da reação social: mudança e permanência de paradigmas criminológicos na ciência e no senso comum. Revista Brasileira de Ciências Criminais, São Paulo, n. 14, p. 276-287, abr./jun. 1996; ANDRADE, Vera Regina Pereira de. A ilusão de segurança jurídica: do controle da violência à violência do controle penal. Porto Alegre: Livraria do Advogado, 2003.

12 BARATTA, Alessandro. Criminologia crítica e crítica do direito penal: introdução à sociologia do direito penal. Rio de Janeiro: Revan, 1999.

13 COHEN, Stanley. Vísiones del control social. Trad. Elena Larrauri. Barcelona: PPU, 1988.

14 GREEME, Helen Taylor; GABBIDON, Shaun L. Race and crime: a text/reader. California: SAGE, 2012.

15 DUARTE, Evandro C. Piza. Criminologia \& racismo. Curitiba: Juruá, 2002. central para resolver os problemas definidos como criminais. Nele, como demonstramos ao tratarmos da recepção da Escola Positiva no Brasil, havia uma estreita vinculação entre teorias da raça e teorias da criminalidade. Logo, os criminólogos positivistas acreditavam existir uma criminalidade diferencial dos afrodescendentes e indígenas que era explicada/justificada com o argumento da inferioridade racial, ou seja, os afrodescendentes e indígenas seriam mais criminosos porque mais inferiores que outros grupos raciais. Nesse momento, portanto, as teorias sobre a criminalidades eram um exemplo evidente de racismo ${ }^{16} 17$

De fato, a crítica a esse racismo teórico evidenciou o uso e a construção da diferença como marcador de poder, demonstrando o "processo de racialização" operado no âmbito da cultural europeia e das relações coloniais ${ }^{18}$. Logo, permitiu identificar a raça como um problema de sociedades que passaram a hierarquizar sistematicamente as diferenças ${ }^{19} 20$

O segundo momento, portanto, ocorre a partir da

16 ARENDT, Hannah. Origens do totalitarismo. Trad. Roberto Raposo. São Paulo: Companhia das Letras, 2012; BARROS, José D’Assunção. A construção social da cor. Petrópolis: Vozes, 2009.

17 Nesse sentido, segundo Mateucci: "O termo racismo se entende, não a descrição da diversidade das raças ou dos grupos étnicos humanos, realizada pela antropologia física ou pela biologia, mas a referência do comportamento do indivíduo à raça a que pertence e, principalmente, o uso político de alguns resultados aparentemente científicos, para levar à crença da superioridade de uma raça sobre as demais. Este uso visa a justificar e consentir atitudes de discriminação e perseguição contra as raças que se consideram inferiores". Cf.: MATTEUCI, Nicola. "Racismo”. In: BOBBIO, Norberto; PASQUINO, Gianfranco; MATEUCCI, Nicola. Dicionário de política. Brasília: Universidade de Brasília, 1993. p. 1061.

18 HALL, Stuart. Da diáspora: identidades e mediações culturais. Organização Liv Sovik; Tradução Adelaine La Guardia Resende. 2. ed. Belo Horizonte: UFMG, 2013.

19 BANTON, Michael. A idéia de raça. São Paulo: M. Fontes, 1991; MUNANGA, Kabengele. Rediscutindo a mestiçagem. Belo Horizonte: Autêntica, 2004; SEGATO, Rita Laura. La nación y sus outro: raza, etnicidad y diversidad religiosa en tiempos de política de la identidad. Buenos Aires: Prometeo Libros, 2007.

20 Nesse sentido, segundo Guimarães, hoje o "Racismo pode, ademais, referir-se não apenas a doutrinas, mas a atitudes (tratar diferencialmente as pessoas de diferentes raças e culturas, ou seja, discriminar) e a preferências (hierarquizar gostos e valores estéticos de acordo com a ideia de raça ou de cultura, de modo a inferiorizar sistematicamente características fenotípicas raciais ou características culturais". Cf.: GUIMARÃES, Antonio Sérgio Alfredo. "Combatendo o Racismo: Brasil, África do Sul e Estados Unidos”. Revista Brasileira de Ciências Sociais, São Paulo, 
década de 1960 e tem sido descrito como uma "revolução de paradigmas científicos" no âmbito da Criminologia (passagem do paradigma etiológico ao paradigma da reação social) e, de modo mais amplo, como marcado por um "impulso desestruturador de desconstrução e deslegitimação do sistema penal" e seus paradigmas, bem como pela crítica do encarceramento como método de abordagem do conflito social. Caracterizou-se, sobretudo, pela emergência de um período de denúncia da violência institucional e da desigualdade de tratamento no sistema de justiça criminal, e por uma estreita vinculação entre teorias críticas do racismo e teorias sobre as funções reais do sistema penal.

Há, portanto, uma mudança decisiva que conduz à descrença das teorias sobre a raça: o reconhecimento de que objeto de estudo deve ser o racismo, ao invés da raça, ou seja, de que o estudo dos comportamentos dos grupos raciais (essencializados em suas identidades) deve dar lugar ao estudo do sistema de poder que exclui determinados grupos sociais. Neste contexto, ao contrário do que ocorria anteriormente, o uso da raça pelos agentes públicos para a identificação de criminosos é denunciado como uma dimensão do racismo, um aspecto da seletividade desse sistema. Os conceitos de vulnerabilidade e seletividade passam a ser decisivos nesse contexto. Os afrodescendentes e indígenas não seriam mais criminosos, mas seriam mais vulneráveis diante da ação seletiva ${ }^{21}$ dos agentes do sistema de justiça criminal. ${ }^{22}$

Ao agir no interior dos sistemas de justiça crimi-

v. 14, n. 39, p. 105, fev. 1999.

21 ANDRADE, Vera Regina Pereira de. "Do paradigma etiológico ao paradigma da reação social: mudança e permanência de paradigmas criminológicos na ciência e no senso comum". Revista Brasileira de Ciências Criminais, São Paulo, n. 14, p. 276-287, abr./jun. 1996; ANDRADE, Vera Regina Pereira de. A ilusão de segurança jurídica: do controle da violência à violência do controle penal. Porto Alegre: Livraria do Advogado, 2003; BARATTA, Alessandro. Criminologia crítica e crítica do direito penal: introdução à sociologia do direito penal. Rio de Janeiro: Revan, 1999; FOUCAULT, Michel. Vigiar e punir: nascimento da prisão. Trad. Raquel Ramalhete. Petrópolis: Vozes, 2011.

22 A visão sobre a criminalidade e as perguntas dirigidas ao campo penal se alteram substancialmente. Vera Andrade ilustra essa passagem: "Desta forma, ao invés de indagar, como a Criminologia tradicional, 'quem é criminoso?', 'por que é que o criminoso comete crime?', o labelling passa a indagar 'quem é definido como desviante?' 'por que determinados indivíduos são definidos como tais?', 'em que condições um indivíduo pode se tornar objeto de uma definição?', 'que efeito decorre desta definição sobre o indivíduo?' 'quem define quem?' e, enfim, com base em que leis sociais se distribui e concentra o poder de definição?”. nal, a seletividade opera de forma quantitativa e qualitativa, determinando as condutas a serem criminalizadas (aquelas mais frequentes entre as classes mais vulneráveis) e as pessoas a serem etiquetadas ${ }^{23}$. Nesse último aspecto, a atuação racista das agências de controle penal tem sido apontada como um elemento fundamental na criminalização da população negra, especialmente dos jovens pobres na periferia.

No plano discursivo, há dois movimentos importantes. O primeiro mais denunciado no âmbito da Criminologia Crítica é o de que a criminologia positivista vincula-se à negatividade do fato colonial. A propósito, sintetizamos ${ }^{24}$ :

[...] o discurso criminológico racista, ao aproximar o criminoso e o "selvagem", adquire novos contornos. Ele pode ser visto como uma ideologia que confundirá a agressividade e a alienação do homem sujeito ao processo de colonização com sua intrínseca maldade, classificando como modo de ser criminal todas as formas de sobrevivência à realidade colonial, as adaptações aos modelos impostos e à violência classificatória sofrida, mas, sobretudo, toda a diversidade humana biológica distinta dos padrões europeus e todas as formas de expressão cultural capazes de possibilitar respostas, ainda que simbólicas, à perda da identidade diante do processo colonizador.

O segundo, pouco estudado no caso brasileiro, são os vínculos entre teorias críticas e a branquidade. Tais vínculos são capazes de demostrar opções teóricas, escolhas metodológicas, esquecimentos e, especialmente, as conexões entre categorias analíticas com uma ordem normativa-hegemônica branca, masculina, burguesa e heterossexual. Assim, ao reconhecer esta ordem, este texto procura se aproximar do conceito de "raça" a partir das suas dimensões históricas e sociais, que incidem, por sua vez, na criação das identidades sociais, afastando noções que percebam a racialização como uma característica unitária, individual e subjetiva ${ }^{25}$.

Cf.: ANDRADE, Vera Regina Pereira de. A ilusão de segurança jurídica: do controle da violência à violência do controle penal. Porto Alegre: Livraria do Advogado, 2003. p. 207.

23 ZAFFARONI Eugenio Raúl. Em busca das penas perdidas: a perda de legitimidade do sistema penal. Tradução de Vânia Romano Pedrosa e Amir Lopes da Conceição. Rio de Janeiro: Revan, 1991. p. 15. Também sobre o tema, cf.: ADORNO, Sérgio. Discriminação racial e justiça criminal. Novos Estudos, São Paulo, n. 43, p. 45-63, nov. 1995.

24 DUARTE, Evandro C. Piza. Criminologia \& racismo. Curitiba: Juruá, 2002. p. 169-170.

25 ZUBERI, Tukufu; BONILLA-SILVA, Eduardo (Ed.). White logic, white methods: racism and methodology. La- 
O terceiro momento sobre o debate é marcado pela convivência contraditória da defesa de propostas de desencarceramento, descriminalização e despenalização, fundamentadas em diversos movimentos de política criminal (abolicionismo, minimalismo, garantismo etc.) e a bifurcação do sistema de justiça criminal, com o crescimento da população submetida sob a forma de medidas de coerção que resultam ou não em encarceramento, e, ao final, pelo aumento da seletividade do sistema penal contra os mesmos grupos vulneráveis ${ }^{26}$. Nesse contexto, como tem demonstrado os estudos estadunidenses e os poucos estudos sobre o tema no Brasil, o encarceramento foi acompanhado de perspectivas tecnificantes da administração da justiça, do discurso sobre "Lei e Ordem" e da difusão da ideia de controle do risco dentro de um modelo de justiça atuarial ${ }^{27}$. Malgrado a pouca presença de discursos abertamente racistas, as agências de controle penal continuam discriminatórias ${ }^{28}$.

Por sua vez, Greene \& Gabbidon ${ }^{29}$, ao inventariarem o amplo debate sobre a raça e crime nos Estados

nham: Plymouth, Rowman \& Littlefield Publishers, 2008.

26 ANDRADE, Vera Regina Pereira de. Do paradigma etiológico ao paradigma da reação social: mudança e permanência de paradigmas criminológicos na ciência e no senso comum. Revista Brasileira de Ciências Criminais, São Paulo, n. 14, p. 276-287, abr./jun. 1996; ANDRADE, Vera Regina Pereira de. A ilusão de segurança jurídica: do controle da violência à violência do controle penal. Porto Alegre: Livraria do Advogado, 2003; COHEN, Stanley. Modelos occidentales utilizados en el tercer mundo para el control del delito: benignos o malignos? Cenipec, Merida, Venezuela, n. 6, p. 63-110, 1984; COHEN, Stanley. Vísiones del control social. Trad. Elena Larrauri. Barcelona: PPU, 1988.

27 FORMIGA, Glêides Simone de. A cor vigiada: uma crítica ao discurso racializado de prevenção ao crime. 2010. Dissertação (Mestrado em Antropologia Social) - Universidade de Brasília, Brasília, 2010; MATTOS, Márcio Júlio da Silva. Reconhecimento, identidade e trabalho sujo na PMDF. 2012. Dissertação (Mestrado em Sociologia) Universidade de Brasília, Brasília, 2012; RAMOS, Silvia; MUSUMECI, Leonarda. Elemento suspeito: abordagem policial e discriminação na cidade do Rio de Janeiro. Rio de Janeiro: Civilização Brasileira, 2005; SILVA, Gilvan Gomes da. A lógica da PMDF na construção do suspeito. 2009. Dissertação (Mestrado em Sociologia) - Universidade de Brasília, Brasília, 2009.

28 DUARTE, Evandro C. Piza. Criminologia \& racismo. Curitiba: Juruá, 2002; FLAUZINA, Ana Luiza Pinheiro. Corpo negro caído no chão: o sistema penal e o projeto genocida do Estado brasileiro. Rio de Janeiro: Contraponto, 2008; SILVA, Gilvan Gomes da. A lógica da PMDF na construção do suspeito. 2009. Dissertação (Mestrado em Sociologia) Universidade de Brasília, Brasília, 2009.

29 GREEME, Helen Taylor; GABBIDON, Shaun L. Race and crime: a text/reader. California: SAGE, 2012.
Unidos, sugerem, no que são seguidos por Zuberi ${ }^{30}$, que há duas referências decisivas, W.E.B. Du Bois e Frantz Fanon, para compreender a relevância dessa variável.

Ambos foram pioneiros na construção da hipótese colonial, ou seja, em atribuir ao colonialismo um papel decisivo na compreensão do racismo e da relação entre os sistemas penais e os afrodescendentes. Ao perceber o colonialismo como uma dominação política e econômica sobre uma unidade política geográfica externa, geralmente habitada por pessoas de raças e culturas diferentes, abriram flanco para se entender a construção da criminologia como uma ciência social a serviço do imperialismo e com repercussões profundas nas realidades pós-coloniais. Evidenciando esta conexão, também contribuíram para a apreensão de que a negligência da pesquisa criminológica contemporânea em relação ao impacto do colonialismo sobre os seus saberes faz parte das permanências e continuidades do modelo colonial na produção do conhecimento ${ }^{31}$.

No mesmo passo, tiveram suas vidas e suas obras marcadas pelo racismo acadêmico, sendo-lhes retirado, no caso de W.E.B. Du Bois, seu papel central na construção do próprio campo da sociologia, e, no caso de Frantz Fanon seu papel decisivo na crítica ao colonialismo.

Em primeiro lugar, W.E.B. Du Bois ${ }^{32}$ empenhou-se em criticar concepções biológicas sobre a situação social dos afro-americanos. Ele foi um analista cuidadoso das barreiras raciais que foram erguidas contra esse grupo, especialmente após o término da Guerra da Secessão e que resultariam na Doutrina dos Separados, mas Iguais. Du Bois percebeu que o "véu da cor" (expressão que indicava o modo como os olhares preconceituosos não conseguiam ver as qualidades de um afro-americano) impedia o desenvolvimento humano pessoal e a integração desse grupo. Restava aos afro-americanos lutarem por sua integração por meio da educação, ao mesmo tempo em que

30 ZUBERI, Tukufu. Más espeso que la sangre: la mentira del análisis estadístico según teorías biológicas de la raza. Traducción de Pablo González: Thicker than blood. How racial statistics lie. Bogotá: Facultad de Ciencias Humanas, Centro de Estudios Sociales (CEs), Grupo de Investigación iDCARÁn, Universidad Nacional de Colombia, 2013.

31 GREEME, Helen Taylor; GABBIDON, Shaun L. Race and crime: a text/reader. California: SAGE, 2012. p. 106-108.

32 DUBOIS, Laurent. Avengers of the new world: the story of the haitian revolution. Harvard: Harvard University Press, 2004. p. 43; e FICK, Carolyn. The making of Haiti: the Saint Domingue Revolution from below. USA: The University of Tennessee Press, 1990. 
denunciavam o preconceito. Antes mesmo da Escola de Chicago, ao analisar dados sobre a Filadélfia, Du Bois defendeu a hipótese de que a criminalidade dos afro-americanos resultaria da "desorganização social" a que estavam expostos, destacando a idade, o desemprego e a pobreza. Entretanto, observou a existência de variáveis discriminadoras no Sistema Penal, especialmente no maior número de prisões de afro-americanos do que de brancos e na maior quantidade de pena atribuída a afro-americanos quando praticavam os mesmos crimes cometidos por brancos ${ }^{33}$.

Neste sentido, argumentava que o sistema policial do sul dos Estados Unidos:

[...] fora preparado para lidar apenas com negros, na pressuposição tácita de que todo homem branco seria ipso facto um membro daquela polícia. Assim, desenvolveu-se um duplo sistema de justiça, que errava quanto aos brancos pela indevida brandura e imunidade prática de criminosos capturados em flagrante delito, e que errava quanto aos negros pelo indevido rigor, pela injustiça e pela falta de discriminação. Pois, como já disse, o sistema policial do sul foi originalmente planejado para controlar todos os negros, não simplesmente criminosos, e, quando os negros foram libertados e todo o sul convenceu-se da impossibilidade de mão-de-obra negra gratuita, o recurso primeiro e quase universal foi utilizar os tribunais de justiça como meio de reescravizar os pretos. Não era, portanto, uma questão de delito, mas sim de cor que decidia, em quase todos os casos, a culpabilidade de alguém. Os negros, por isso, passaram a considerar os tribunais como instrumentos de injustiça e opressão, e seus condenados como mártires e vítimas ${ }^{34}$

A ocultação, por parte do racismo institucional acadêmico, das contribuições de W. E.B Du Bois para a Sociologia Norte-Americana e, sobretudo, para a Criminologia representam, no debate atual, um déficit importante de décadas de pesquisas. Ele foi o primeiro a coletar, junto com seus estudantes, dados empíricos sobre as relações raciais nos EUA, contribuindo para a revolução paradigmática (sempre inconclusa) do debate sobre a raça. A partir de sondagens raciais na cidade de Filadélfia, Du Bois afirmou que o estudo da população afro-americana se dividia em duas categorias: a dos afro-americanos en-

33 GREEME, Helen Taylor; GABBIDON, Shaun L. Race and crime: a text/reader. California: SAGE, 2012. p. 97-100.

34 DUBOIS, Laurent. Avengers of the new world: the story of the Haitian Revolution. Harvard: Harvard University Press, 2004. p. 43; e FICK, Carolyn. The making of Haiti: the Saint Domingue Revolution from below. USA: The University of Tennessee Press, 1990. p. 228-229. quanto grupo social e a de seu entorno social particular. Desta forma, a raça se convertia em um sintoma e não em uma casa, já que, enquanto construção histórica, é resultado dos processos vividos pelas comunidades ${ }^{35}$.

Foram os seus estudos que começaram a mostrar as segregações a que eram submetidos diversos grupos raciais e as formas como esses eram oprimidos. Muitos dos resultados das análises evidenciaram um sistema econômico desigual e barreiras culturais para a inclusão, de onde surgiu a perspectiva estatística que tem como foco a cultura ${ }^{36}$. Como coloca Tukufu Zuberi, a perspectiva de Du Bois deslocou a forma moderna de se fazer pesquisas estatísticas, as quais, mesmo quando não se encontram dentro do marco da eugenia, legitimam o uso de metodologias que perpetuam os problemas que querem superar. Quer dizer, "empregar a estatística racial e implementar a raça como uma causa leva à essencialização da raça como variável, o que mantém uma ideia de classificação e de estratificação racial”"37.

Em segundo lugar, se Du Bois analisou as barreiras de segregação racial construídas na "democracia capitalista americana", Frantz Fanon foi crítico do Colonialismo, especialmente o francês e seu impacto no Caribe e na África. A viragem proposta pelo médico psiquiatra martinicano foi surpreendente. $\mathrm{O}$ alvo de Fanon não foi apenas as falsas concepções científicas sobre os negros e suas teses sobre a inferioridade racial, mas também as reações dos indivíduos racializados. Ninguém mais do que Fanon ousou em sua época pensar sobre os efeitos da interpelação social contida na palavra negro. Já em "Pele Negra, Máscaras Brancas", a crítica ao psicanalista

35 ZUBERI, Tukufu. Más espeso que la sangre: la mentira del análisis estadístico según teorías biológicas de la raza. Traducción de Pablo González: Thicker than blood. How racial statistics lie. Bogotá: Facultad de Ciencias Humanas, Centro de Estudios Sociales (CEs), Grupo de Investigación iDCARÁn, Universidad Nacional de Colombia, 2013. p. 143-147.

36 ZUBERI, Tukufu. Más espeso que la sangre: la mentira del análisis estadístico según teorías biológicas de la raza. Traducción de Pablo González: Thicker than blood. How racial statistics lie. Bogotá: Facultad de Ciencias Humanas, Centro de Estudios Sociales (CEs), Grupo de Investigación iDCARÁn, Universidad Nacional de Colombia, 2013. p. 147-148.

37 ZUBERI, Tukufu. Más espeso que la sangre: la mentira del análisis estadístico según teorías biológicas de la raza. Traducción de Pablo González: Thicker than blood. How racial statistics lie. Bogotá: Facultad de Ciencias Humanas, Centro de Estudios Sociales (CEs), Grupo de Investigación iDCARÁn, Universidad Nacional de Colombia, 2013. p. 158. 
Octave Manonni sugere pensar o comportamento dos colonizados não como um complexo de inferioridade, mas como um processo de violência que atingiria a própria subjetividade ${ }^{38}$. De certo modo, ainda nesse momento, o autor olha mais para as doenças que teriam causas sociais resultantes do colonialismo do que o próprio colonialismo. Ao falar desse complexo e das impossibilidades de realização do eu do colonizado nas realidades coloniais, ele sintetizava:

Todo povo colonizado - isto é, todo povo no seio do qual nasceu um complexo de inferioridade devido ao sepultamento de sua originalidade cultural - toma posição diante da linguagem da nação civilizadora, isto é, da cultura metropolitana.

Quanto mais assimilar os valores culturais da metrópole, mais o colonizado escapará da sua selva. Quanto mais ele rejeitar sua negridão, seu mato, mais branco será.

[...] No momento em que eu esquecia, perdoava e desejava apenas amar, devolviam-me, como uma bofetada em pleno rosto, minha mensagem! O mundo branco, o único honesto, rejeitava minha participação. De um homem exige-se uma conduta de homem; de mim, uma conduta de homem negro - ou pelo menos uma conduta de preto. Eu acenava para o mundo e o mundo amputava meu entusiasmo. Exigiam que eu me confinasse, que encolhesse ${ }^{39}$.

Todavia, em "Os Condenados da Terra", a doença colonial é exposta em sua dimensão estrutural. A obra representa um avanço das percepções do autor relacionadas à sua própria experiência individual de envolvimento com as lutas por libertação no continente africano. Nela, argumenta-se no sentido de demonstrar como o colonialismo se entranhou em todos os rincões da vida, em que o colonizado tem o passado e suas terras roubadas. Assim, o contexto colonial dividiu o mundo em dois: as sociedades capitalistas, local onde residem supostamente as instituições democráticas, a moral e a ordem; e as colônias, em que o interlocutor imediato com o colonizado é a linguagem da pura violência (o exército, a polícia, o napalm, etc $)^{40}$. Ao ignorar qualquer padrão de racionalidade e instaurar o medo como hábito cotidiano, o colonialismo estrutura um imaginário e uma materialidade

$38 \quad$ FANON, Frantz. Pele negra, máscaras brancas. Trad. Renato da Silveira. Salvador: EdUFBA, 2008. p. 85 e ss.

39 FANON, Frantz. Pele negra, máscaras brancas. Trad. Renato da Silveira. Salvador: EdUFBA, 2008. p. 34-107.

$40 \quad$ FANON, Frantz. Os condenados da terra. Trad. Enilce Albergaria Rocha, Lucy Magalhães. Juiz de Fora: UFJF, 2005. p. 54 sobre o "Outro". Fanon assim expõe essa dinâmica:

O questionamento do mundo colonial pelo colonizado não é um confronto racional dos pontos de vista. Não é um discurso sobre o universal, mas a afirmação passional de uma originalidade apresentada como absoluta. O mundo colonial é um mundo maniqueísta. Não basta ao colono limitar fisicamente, isto é, com seus policiais e guardas, o espaço do colonizado. Como que para ilustrar o caráter totalitário da exploração colonial, o colono faz do colonizado uma espécie de quintessência do mal. A sociedade colonizada não é apenas descrita como uma sociedade sem valores. Não basta ao colono afirmar que os valores desertaram, ou melhor, nunca habitaram, o mundo colonizado. $\mathrm{O}$ indígena é declarado impermeável à ética. Ausência de valores, e também negação dos valores. Ele é, ousemos dizer, o inimigo dos valores. Nesse sentido, ele é o mal absoluto. Elemento corrosivo, destruindo tudo o que se refere à estética ou à moral, depositário de forças maléficas, instrumento inconsciente e irrecuperável de forças cegas ${ }^{41}$.

Neste contexto, a hipótese colonial traz para o centro do debate novas perspectivas que propõe uma releitura de categorias fundamentais, especialmente, a Modernidade, a Igualdade e a Liberdade. Histórias de liberdade ou histórias de opressão, e seus respectivos modelos de controle social, necessitam ser reescritas a partir de outros novos olhares, considerando sempre que as identidades, especialmente as referentes à nacionalidade e ao discurso universalista, ocultam representações dominantes ${ }^{42}$.

A densidade dessa literatura não permite um crítica única, porém, elas sugerem a releitura das categorias sobre controle social a partir de uma história das ideias que considere as novas contribuições trazidas pelo Feminismo (Criminologias Feministas) ${ }^{43}$, a Teoria Queer ${ }^{44}$, o

$41 \quad$ FANON, Frantz. Os condenados da terra. Trad. Enilce Albergaria Rocha, Lucy Magalhães. Juiz de Fora: UFJF, 2005. p. 57-58.

42 DUARTE, Evandro C. Piza; QUEIROZ, Marcos V. Lustosa. A Revolução Haitiana e o Atlântico Negro: o constitucionalismo em face do lado oculto da modernidade. Brasília, 2016 (no prelo).

43 ANDRADE, Vera Regina Pereira de. Criminologia e feminismo: da mulher como vítima à mulher como sujeito de construção da cidade. Sequência, Florianópolis, v. 35, p. 42-49, p. 1997; CAMPOS, Carmen Hein de Campos. Teoria crítica feminista e crítica às criminologias: estudo para uma perspectiva feminista em criminologia no Brasil. 2013. Tese (Doutorado) - Ciências Criminais pela Pontifícia Universidade Católica do Rio Grande do Sul, Rio Grande do Sul, 2013; MENDES, Soraia da Rosa. Criminologia feminista: novos paradigmas. São Paulo: Saraiva, 2014.

44 CARVALHO, Salo. Sobre a criminalização da homofobia: perspectivas desde a criminologia queer. Revista Brasileira 
Pensamento Decolonial ${ }^{45}$ e o Pensamento Negro ${ }^{46}$. Tais perspectivas trouxeram para o centro da disputa acadêmica temas importantes como a especificidade, a transversalidade e a interseccionalidade das relações de poder.

De modo direto, tais perspectivas contribuíram especialmente para a construção de uma metodologia de diversificação da análise das relações de poder que colocam sob suspeita os usos discursivos das narrativas históricas para a representação política: de fato, toda representação que se pretenda não dominante deve ser sempre colocada "sob suspeita" da mesma forma que as representações dominantes. Os críticos contemporâneos do poder não devem ter mais tanta facilidade em falar em nome de uma "classe oprimida" ou de um "povo". Os "subalternos" são múltiplos. Logo, mesmo as histórias críticas do controle social parecem insuficientes quando não consideram, por exemplo, as formas de sujeição das mulheres, a aculturação forçada dos indígenas, o genocídio, o epistemicídio, a racialização dos corpos, a heteronormatividade, a homofobia, a exploração sexual das mulheres e dos homossexuais etc. A história dos "subalternos" é, e deve permanecer sendo, um "terreno minado".

A Modernidade, pensada a partir de Dussel ${ }^{47}$, revela para além do caráter positivo, construído a partir da racionalidade discursiva, o seu caráter negativo que pode ser sintetizada no "fato colonial". Todavia, "sob suspeita", o fato colonial, descrito em sua negatividade oculta o movimento paradoxal de indivíduos, grupos e

de Ciências Criminais, São Paulo, v. 99, p. 187-211, 2012a; CARVALHO, Salo. Sobre as possibilidades de uma criminologia queer. Sistema Penal \& Violência (Online), v. 4, p. 152-168, 2012b.

45 ALCOFF, Linda Martín. Uma epistemologia para a próxima revolução. Revista Sociedade e Estado, Brasília, v. 31, n. 1, p. 129-143 jan./abr. 2016; BERNARDINOCOSTA, Joaze. Saberes subalternos e decolonialidade: os sindicatos das trabalhadoras domésticas no Brasil. Brasília: Universidade de Brasília, 2015; MIGNOLO, Walter. Historias locales: diseños globales. Colonialidad, conocimientos subalternos y pensamiento fronterizo. Trad. Juan María Madariaga y Cristina Vega Solís. Madrid: Akal, 2003.

46 BERNARDINO-COSTA, Joaze; GROSFOGUEL, Ramón. "Decolonialidade e perspectiva negra". Sociedade e Estado, Brasília, v. 31, p. 15-24, 2016; COLLINS, Patricia Hill. Black feminist thought: knowledge, consciousness, and the politics of empowerment. Nova York: Routledge, 2009; CRENSHAW, Kimberlé et al (Ed.). Critical race theory. Nova York: The New Press, 1995; GILROY, Paul. O Atlântico Negro. Trad. Cid Knipel Moreira. 2. ed. São Paulo: 34, 2012;

47 DUSSEL, Enrique. 1492: o encobrimento do outro: a origem do mito da modernidade: Conferências de Frankfurt. Trad. Jaime A. Clasen. Petrópolis: Vozes, 1993. sociedades na resistência criativa na Modernidade, uma positividade dos subalternos, e a compreensão de que as estratégias de controle social respondem, sobretudo, a esses efeitos. Esse movimento paradoxal de resistência criativa, especialmente para os escravizados africanos, tem sido trazido à tona pelos "Estudos Culturais" e, especificamente, por Paul Gilroy e Stuart Hall ${ }^{48}$. Ao mesmo tempo em que o silêncio acadêmico sobre o tema pode ser compreendido pelas formas racializadas de construção do conhecimento. Tema desenvolvido pelos estudos sobre a branquidade e racismo institucional, os quais são decisivos para a compreensão dos campos acadêmicos, inclusive críticos ${ }^{49}$.

Malgrado a abordagem introdutória, nesse contexto destacam-se algumas questões centrais na construção de uma hipótese colonial sobre o sistema penal moderno.

A primeira questão refere-se ao uso de novas categorias compreensivas da Modernidade, tais como "Atlântico Negro" e "Diáspora Africana". Elas destacam o caráter local, continental e universal das revoltas dos escravizados, as novas dinâmicas da escravidão nas cidades, a escravidão urbana e as disputas em torno do domínio da "cidade negra", os fluxos de ideias e pessoas no tráfico continental, as lutas simbólicas em relação a modelos culturais e sua reinvenção, as construções subjetivas da diáspora africana e, em menor medida, as diásporas internas dos povos originários.

A segunda questão, relacionada à anterior, é a importância dos escravizados negros na "era das revoluções" e, especialmente na Revolução do Haiti, com a reinterpretação dos princípios do Iluminismo e agenciamento de lutas pelo fim da escravidão negra. A igualdade racial não foi oferecida, ela foi conquistada e continuo disputada ao longo do século XIX. A Revolução do Haiti marcará uma virada nos discursos e estratégias de controle social. A erupção da igualdade racial revolucionária possui um vinculo direto com a consolidação da desigualdade racial proposta pela ciência. Somente os movimentos de produção e contestação de hierarquias raciais e de especialização de discursos no âmbito da esfera ideológica são capazes de elucidar a dinâmica política da construção do

48 HALL, Stuart. Da diáspora: identidades e mediações culturais. Organização Liv Sovik; Tradução Adelaine La Guardia Resende. 2. ed. Belo Horizonte: UFMG, 2013.

49 WARE, Vron. Branquidade: identidade branca e multiculturalismo. Rio de Janeiro: Garamond, 2004. 
sistema penal a partir de padrões racializados ${ }^{50}$.

\section{As"fronteiras" e as "territorialidades" na "for- mação do controle social no Brasil": o Atlân- tico Negro, a Diáspora Africana e as Cidades Negras}

O conceito de "Atlântico Negro" de que fala Paul Gilroy, permite trazer ao debate uma noção de cultura, ou antes, de uma "transcultura negra" ${ }^{11}$, mais dinâmica e mais fluida, capaz de compreender a história das nações e das nacionalidades não enquanto acontecimentos estanques, mas como processos inter-relacionados. Na definição dada pelo autor: "as formas culturais estereofônicas, bilíngues ou bifocais originadas pelos - mas não mais propriedade exclusiva dos - negros dispersos nas estruturas de sentimento, produção, comunicação e memória, a que tenho chamado heuristicamente mundo atlântico negro" 52 .

É em razão de tais aspectos que o "Atlântico Negro" precisa ser pensado junto a outro conceito, o de diáspora. "Como uma alternativa à metafísica da 'raça', da nação e de uma cultura territorial fechada, codificada no corpo, a diáspora é um conceito que ativamente perturba a mecânica cultural e histórica do pertencimento" ${ }^{33}$. A diáspora é o conceito que desafia os nacionalismos ao explorar os vínculos sub e supranacionais, "[...] permitindo uma relação mais ambivalente com as nações e com o nacionalismo" ${ }^{\prime 54}$. É isso o que Gilroy chama de uma propensão "não-nacional" da diáspora, ${ }^{55}$ dependente de uma visão

50 DUARTE, Evandro C. Do medo da diferença à igualdade como liberdade: as ações afirmativas para negros no ensino superior e os procedimentos de identificação de seus beneficiários. 2011. Tese (Doutorado) - Universidade de Brasília, Brasília, 2011.

51 GILROY, Paul. O Atlântico Negro. Trad. Cid Knipel Moreira. 2. ed. São Paulo: 34, 2012. p. 15.

52 GILROY, Paul. O Atlântico Negro. Trad. Cid Knipel Moreira. 2. ed. São Paulo: 34, 2012. p. 35.

53 GILROY, Paul. O Atlântico Negro. Trad. Cid Knipel Moreira. 2. ed. São Paulo: 34, 2012. p. 18.

54 GILROY, Paul. O Atlântico Negro. Trad. Cid Knipel Moreira. 2. ed. São Paulo: 34, 2012. p. 19.

55 Essa dimensão "política", por assim dizer, do conceito de diáspora e, claro, do de "Atlântico Negro" é assim explicitada: "A propensão não-nacional da diáspora é ampliada quando o conceito é anexado em relatos não-essencialistas da formação de identidades primordiais que se estabelecem supostamente tanto pela cultura quanto pela natureza. Ao aderir à diáspora, a identidade pode ser, ao invés disso, levada à contingência, à indeterminação e ao conflito". Cf.: GILROY, Paul. O Atlântico Negro. Trad. Cid Knipel não essencialista das identidades, desterritorializando- as $^{56}$ e explorando os pontos de contato das narrativas, os fluxos e a contingência ${ }^{57}$.

A multiplicidade pretendida por Gilroy é dependente de uma reinterpretação do próprio conceito de diáspora em sua forma tradicional. Para o autor, o empreendimento do "Atlântico Negro" depende de um conceito de diáspora de certa forma consciente desses intercâmbios contínuos:

Este desenvolvimento está conectado com a transformação da ideia mais antiga, uni-direcionada, da diáspora como uma forma de dispersão catastrófica mas simples, que possui um momento original identificável e reversível - a sede do trauma - em algo bem mais complexo e frutífero" 58

Nesse ponto, a abordagem de Gilroy se aproxima da de Stuart Hall, envolvido em uma crítica daquilo que chama de um "conceito fechado de diáspora"59. Hall dá a essa abordagem tradicional da diáspora tratamento semelhante ao dado por Gilroy, afirmando estar ela fundada "[...] sobre a construção de uma fronteira de exclusão" e dependente “[...] da construção de um 'Outro’ e de uma oposição rígida entre o dentro e o fora" ${ }^{60}$. É preciso um conceito capaz de dar conta da complexidade dos fluxos comunicativos e que não recaia nos binarismos do "original” e da "cópia”, da "influência” e do "influenciado". É em razão disso que o conceito de diáspora, assim como o projeto do "Atlântico Negro", não se amolda às frontei-

Moreira. 2. ed. São Paulo: 34, 2012. p. 19.

56 O uso de "desterritorialização", bastante comum em um filósofo como Gilles Deleuze, é do próprio Gilroy: "Mas acima disso, como já disse, ela frisa uma reconceitualização da cultura a partir do sentimento de sua desterritorialização". Cf.: GILROY, Paul. O Atlântico Negro. Trad. Cid Knipel Moreira. 2. ed. São Paulo: 34, 2012. p. 22.

57 De certa forma, o conceito de diáspora demanda uma concepção não linear e não teleológica da história e do processo de formação das identidades: "A rede que a análise da diáspora nos ajuda a fazer pode estabelecer novas compreensões sobre o self, a semelhança e a solidariedade. No entanto, os pontos ou nós que compõem esta nova constelação não são estágios sucessivos num relato genealógico de relações de parentesco". E continua: "Não se produz o futuro a partir de uma sequência de teleologia étnica. Nem tampouco são eles pontos de uma trajetória linear em direção ao destino que a identidade africana representa”. Cf.: GILROY, Paul. O Atlântico Negro. Trad. Cid Knipel Moreira. 2. ed. São Paulo: 34, 2012. p. 20.

58 GILROY, Paul. O Atlântico Negro. Trad. Cid Knipel Moreira. 2. ed. São Paulo: 34, 2012. p. 19-20.

59 HALL, Stuart. Da diáspora, identidades e mediações culturais. Belo Horizonte: UFMG, 2013. p. 32.

60 HALL, Stuart. Da diáspora, identidades e mediações culturais. Belo Horizonte: UFMG, 2013. p. 32-33. 
ras do Estado-nacional. ${ }^{61}$ E não se ajusta em razão de ser a própria cultura algo continuamente produzido ${ }^{62}$ e não uma entidade sedimentada e que se transmite em via única: “[...] a cultura não é apenas uma viagem de redescoberta, uma viagem de retorno. Não é uma 'arqueologia'. A cultura é uma produção"63.

A diáspora e o Atlântico Negro reinterpretam, nesse sentido, a própria noção de espaço, algo útil para se falar de cidades negras, já que insistem na ideia de um fluxo comunicativo e não mais em um processo de influências unilaterais. Nas palavras do autor: "O conceito de espaço é em si mesmo transformado quando ele é encarado em termos de um circuito comunicativo que capacitou as populações dispersas a conversar, interagir e mais recentemente até a sincronizar significativos elementos de suas vidas culturais e sociais" ${ }^{4}$. O espaço se torna, assim, "espaço da diáspora”, ou antes, espaço que constitui a diáspora e por ela também é constituído.

As cidades negras partem, assim, de um conceito de cidade pensado a partir da diáspora e dessa ressignificação do espaço antes mencionada. São cidades transatlânticas, a exemplo do Rio de Janeiro e de Salvador, onde circulavam pessoas, ideias de liberdade, igualdade, insurreições, motins, práticas culturais não oficiais, mercadorias legais e ilegais, homens e mulheres, escravos, libertos e foragidos. Cidades que, além de possuírem uma grande população negra, produziam sua própria identidade, cotidianamente reinventada: "Africanos e crioulos não eram necessariamente uma multidão ou massa escrava nos centros urbanos. Os recém-chegados produziam identidades diversas, articulando as denominações do tráfico, aquelas senhoriais e a sua própria reinvenção em

61 Na lição de Hall: "A relação entre as culturas caribenhas e suas diásporas não pode, portanto, ser adequadamente concebida em termos de origem e cópia, de fonte primária e reflexo pálido. Tem de ser compreendida como a relação entre uma diáspora e outra. Aqui, o referencial nacional não é muito útil. Os Estados-nação impõem fronteiras rígidas dentro das quais se espera que as culturas floresçam". CF.: HALL, Stuart. Da diáspora, identidades e mediações culturais. Belo Horizonte: UFMG, 2013. p. 34.

62 Stuart Hall chama esse fenômeno de um contínuo "processo de formação cultural", de maneira que "A cultura não é uma questão de ontologia, de ser, mas de se tornar". Cf.: HALL, Stuart. Da diáspora, identidades e mediações culturais. Belo Horizonte: UFMG, 2013. p. 43.

63 HALL, Stuart. Da diáspora, identidades e mediações culturais. Belo Horizonte: UFMG, 2013. p. 43.

64 GILROY, Paul. O Atlântico Negro. Trad. Cid Knipel Moreira. 2. ed. São Paulo: 34, 2012. p. 20-21. determinados cenários”65. Há uma dimensão "não-nacional" das cidades negras, no sentido proposto por Gilroy e também por Hall: tais “territórios negros” existiam muito antes da própria existência dos Estados nacionais constituídos. Além disso, a produção cultural que ocorria nesses espaços, num processo contínuo de reinvenção, não se limitava aos contornos estreitos das fronteiras nacionais.

As cidades negras são o território da "trans-cultura negra”, em que, ao contrário de um processo de influência unilateral da África sobre esses territórios localizados do outro lado do Atlântico, havia um verdadeiro processo de criação contínua, no qual "Áfricas” eram recriadas. ${ }^{66}$ Desse modo, "[...] espalhados pelas cidades negras, [muitos africanos e seus descendentes] recriavam redes culturais peculiares, de diferentes tradições religiosas vivenciadas por eles mesmos, ou por seus pais e avós. Algumas reinventadas deste lado do Atlântico"67.

O realizar dessa outra periodização da história, com enfoque no Atlântico Negro, ${ }^{68}$ ilumina a importância que a realidade marítima teve ao criar um campo de trocas culturais e políticas que transbordam as fronteiras nacionais e étnicas. Ainda distante da existência do barco a vapor, as correntes planetárias facilitaram a transmissão circular da experiência humana e o desenvolvimento das práticas coloniais. Contra as forças centralizadoras, ordenadoras e uniformizadoras dos estados-nação, o

65 FARIA, Juliana Barreto et al. Cidades Negras: africanos, crioulos e espaços urbanos no Brasil escravista do século XIX. Rio de Janeiro: Alameda, 2006. p. 13.

66 Os autores mencionam a participação significativa dos espaços religiosos nesse processo: "Em pequenos casebres, salas e quartos diminutos, em espaçosos terreiros, ou mesmo nos casarões senhoriais, muitos africanos e seus descendentes procuraram, a todo custo, celebrar seus deuses e antepassados". Cf.: FARIA, Juliana Barreto et al. Cidades Negras: africanos, crioulos e espaços urbanos no Brasil escravista do século XIX. Rio de Janeiro: Alameda, 2006. p. 123. Além da religiosidade, da capoeira e das festas, os batuques também exerceram importante papel nesse processo de organização da cultura negra urbana. Sobre o tema, cf.: FARIA, Juliana Barreto et al. Cidades Negras: africanos, crioulos e espaços urbanos no Brasil escravista do século XIX. Rio de Janeiro: Alameda, 2006. p. 123-152.

67 FARIA, Juliana Barreto et al. Cidades Negras: africanos, crioulos e espaços urbanos no Brasil escravista do século XIX. Rio de Janeiro: Alameda, 2006. p. 123.

$68 \mathrm{O}$ argumento, trabalhado ao longo do texto, sobre a importância do conceito de Atlântico Negro para deslocar as perspectivas filosóficas, históricas e políticas em relação à Modernidade e ao colonialismo foi primeiramente articulado em: DUARTE, Evandro C. Piza; QUEIROZ, Marcos V. Lustosa. A Revolução Haitiana e o Atlântico Negro: o constitucionalismo em face do lado oculto da modernidade. Brasília, 2016 (no prelo). 
Atlântico se formou como entremeio de uma multidão multiétnica essencial ao surgimento do capitalismo globalizado, a qual, em sua época, foi reprimida pela expansão do colonialismo e que, hoje, é invisibilizada por um fazer da história refém ao modelo das grandes narrativas clássicas modernas ${ }^{69}$.

Em sua circularidade discursiva, o Atlântico também atuou como canal de aprendizado das elites coloniais, as quais, a partir das diversas experiências de conhecimento-exploração, seja na África ou nas Américas, foram desenvolvendo maneiras de lidar com as possíveis resistências e lutas dos grupos subalternizados. Por meio do gerenciamento de identidades e diferenças, do aperfeiçoamento dos modelos de violência, da criação de legitimadores discursivos, do controle populacional, do entendimento topográfico e climático e outras práticas, uma rede de saber-poder atlântica, pertencente as elites coloniais, foi sendo construída e remodelada no decorrer dos séculos ${ }^{70}$.

A dinâmica do Atlântico Negro serve também para descavar o impacto, a escala e a extensão da violência proveniente do "encontro colonial" novas realidades até então inexistentes. O colonialismo, com seus efeitos globalizados, instaurou uma nova ordem à força, deformando antigos e conformando novos padrões sociais nas ditas sociedades periféricas. De um dia para o outro, as metafísicas das populações colonizadas, com seus costumes, instâncias simbólicas e expressividades culturais, foram abaladas porque estavam em contradição com uma sociedade que não conheciam e que lhes foi imposta. O ser desses povos passa a ser constituído violentamente como um ser diante do mundo ocidental, branco e europeu, que lhes obriga a se situar perante dois sistemas de referência ${ }^{72}$.

O que é trazido ao primeiro plano é a dimensão ontologicamente criadora da violência, seja por parte das práticas colonizadoras, seja por parte da resistência

69 LINEBAUGH, Peter; REDIKER, Marcus. A hidra de muitas cabeças: marinheiros, escravos, plebeus e a história oculta do Atlântico revolucionário. Trad. Berilo Vargas. São Paulo: Cia das Letras, 2008.

70 ALENCASTRO, Luiz Felipe de. O trato dos viventes: formação do Brasil no Atlântico Sul. São Paulo: Cia. das Letras, 2000.

71 CONNEL, Raewyn. A iminente revolução na teoria social. Revista Brasileira de Ciências Sociais, São Paulo, v. 27. n. 80, p. $09-20$, out. 2012

72 FANON, Frantz. Os condenados da terra. Trad. Enilce Albergaria Rocha, Lucy Magalhães. Juiz de Fora: UFJF, 2005. do colonizado diante das impossibilidades que lhe foram legadas. O colonialismo e a escravidão instauraram um sistema de comunicação extremamente assíncrono, radicalmente dividido pelos interesses econômicos e políticos opostos $^{73}$. Totalmente diferente de qualquer descrição de uma esfera pública pautada por instâncias discursivas de alteridade e reconhecimento ${ }^{74}$, a "arena política", na qual negros e negras se encontravam, era formada por um espaço comunicativo extremamente restrito, sendo necessárias formas alternativas de mediação com o real.

Articulando o reconhecimento de uma violência original do colono como "aparecimento", as diversas formas de lutas das populações do Atlântico Negro enfocaram a ideia de que "o homem colonizado se liberta na e pela violência”, pois é por meio dela que o subalternizado age enquanto positividade formadora. Enquanto elemento de mediação, a violência direciona meios e fins para uma causa e história coletivas, gerando reconhecimento e antevisão de um futuro comum ${ }^{75}$.

Assim, o Atlântico permite compreender as duas facetas da violência enquanto dimensões constituintes da Modernidade globalizada. Primeiramente como violência colonial, força que regionaliza, diferencia e desterritorializa diferentes tradições, expressa também no genocídio populacional e aniquilamento cultural. E, no segundo sentido, enquanto violência anticolonial, unificadora e totalizadora, capaz de reestabelecer o fluxo linguístico interrompido pela violência original do colonialismo. ${ }^{7677}$

73 GILROY, Paul. O Atlântico Negro. Trad. Cid Knipel Moreira. 2. ed. São Paulo: 34, 2012.

74 KELLNER, Douglas. Habermas, the public sphere, and democracy: a critical intervention. In: HAHN, Lewis Edwin. Perspectives on Habermas. USA: Open Court, 2000. p. 259-287.

75 FANON, Frantz. Os condenados da terra. Trad. Enilce Albergaria Rocha, Lucy Magalhães. Juiz de Fora: UFJF, 2005.

76 Nada melhor que as próprias palavras de Fanon para explicitar as duas dimensões constituidoras da violência em sociedades afetadas pelo colonialismo: "A existência da luta armada indica que o povo decide só confiar nos meios violentos. Aquele a quem sempre se disse que ele só compreendia a linguagem da força decide expressar-se pela força. Efetivamente desde sempre, o colono lhe mostrou o caminho que deveria ser o seu, se quisesse libertar-se. $\mathrm{O}$ argumento que o colonizado escolhe lhe foi indicado pelo colono e, por uma irônica inversão das coisas, é o colonizado que, agora, afirma que o colonialista só compreende a força”. Cf.: FANON, Frantz. Os condenados da terra. Trad. Enilce Albergaria Rocha, Lucy Magalhães. Juiz de Fora: UFJF, 2005. p. 102.

77 Obviamente que a filosofia ocidental já tematizou a violência das mais diversas formas, inclusive reconhecendo o seu caráter constitutivo de relações sociais. Walter Benjamin, 


\section{A Revolução do Haiti como ponto de tensão dos discursos sobre o medo e a raça}

O Atlântico Negro produziu inúmeras tensões sociais, porém o vocabulário político (revoltas, rebeliões,

Carl Schmitt e Jacques Derrida são exemplos de pensadores que trabalharam a dimensão violenta por trás da institucionalização de arcabouços normativos (como o direito), os quais, muitas vezes sob legitimadores míticos das suas próprias estruturações (como discursos sobre justiça), encerram possibilidades alternativas sobre o real. Portanto, a exposição da violência inerente a toda metafísica argumentativa não é algo novo. Sobre o tema, cf.: BENJAMIN, Walter. Crítica da violência: crítica do poder. Revista Espaço Acadêmico, Maringá, ano 2, n. 21, fev. 2003; SCHMITT, Carl. O conceito do político/Teoria do Partisan. Trad. Geraldo de Carvalho. Belo Horizonte: Del Rey, 2008; DERRIDA, Jacques. Força de lei: o fundamento místico da autoridade. Trad. Leyla Perrone-Moisés. São Paulo: M. Fontes, 2010. Por outro lado, o que se quer trazer como novidade a respeito da violência por meio do Atlântico Negro é justamente o apagamento que as mesmas narrativas hegemônicas sobre a violência realizam, que é o silêncio sobre as violências e estruturações decorrentes do encontro colonial. É apontar a inexistência da Modernidade (e de todos os seus respectivos sistemas de pensar) sem o colonialismo, ou melhor, que se há Modernidade, ela se constitui enquanto Modernidade-colonialidade. É dizer que até nas narrativas mais "cruas" sobre a violência do mundo moderno, há uma violência racializada e colonial justamente por não reconhecer, negar ou ocultar a violência sofrida pelos negros e negras na diáspora. Justamente neste ponto, por exemplo, é que pode ser traçada divergências entre o pensamento de Fanon e Benjamin, em que o primeiro acredita que certos conceitos como o de "luta de classes" não são suficientes para explicar os processos sofridos pelas pessoas de cor no colonialismo, evidenciando como o objeto de preocupação do alemão, ainda que dotado de ares de universalidade, era precipuamente europeu. Cf.: GUIMARÃES, Johnatan Razen Ferreira. Coordenadas do possível: o lugar da violência e a legitimidade da ocupação de terras na ADI 2.213-0. 2015. Dissertação (Mestrado em Direito) - Universidade de Brasília, Brasília, 2015.

Por outro lado, Pedro Henrique Argolo Costa aponta que no conceito de nomos da terra schmittiano é possível encontrar, mais do que em outras noções filosóficas metropolitanas, um instrumento metodológico, enraizado na própria tradição europeia, capaz de realizar um duplo deslocamento: a possibilidade de uma filosofia da história reorientada pelo evento da "Conquista" (do colonialismo) e uma estratégia de leitura com força crítica suficiente para lançar ao texto europeu uma certa "desconfiança" sobre sua pretensa universalidade. Cf.: COSTA, Pedro Henrique Argolo. Entre hidra e leviatã: o nomos da terra de Carl Schmitt e o paradoxo da história universal. 2016. TCC (Monografia em Direito) - Universidade de Brasília, Brasília, 2015. p. 58. De qualquer maneira, aponta-se para a importância do encontro colonial - e da sua respectiva violência - para se tentar reconstituir narrativas que questionem mais atentamente os limites e fronteiras das pretensões modernas de universalidade (sejam filosóficas, de discurso, de poder ou de direitos). sedições, insurreições etc.) criou outras inúmeras formas de confinamento histórico das dimensões desses processos. Não obstante, mais recentemente, a Revolução Haitiana (1791), tem emergido como um momento decisivo na "Era das Revoluções" para pensar as diversas estratégias construídas no Atlântico Negro, pois desembocará na declaração do primeiro Estado negro independente em 1805 e na primeira auto-declaração de um território livre da escravidão negra, sob a forma constitucional. Durante esse período, inúmeras discussões e disputas serão realizadas nos dois lados do Atlântico a respeito das ideias de igualdade, liberdade, raça, colonialismo, nacionalidade e cidadania, as quais tensionariam as fronteiras das pretensões universalistas dos princípios revolucionários do ocidente. De modo direto, na sequência da reação napoleónica ao fim da escravidão e à independência das colônias, em oposição à São Domingos, ergue-se a teorias das raças.

A insurgência de São Domingos foi gestada em um imenso caldeirão cultural, em que a religião, as diferenças linguísticas, as organizações comunitárias alternativas e o hábito das plantations desempenharam papel crucial nos rumos das movimentações de negros e negras. $\mathrm{O}$ vodu, ${ }^{78}$

78 A historiografia contemporânea atribui um papel bastante importante ao vodu como instância mediadora dos diversos grupos de escravos em São Domingos, bem como uma "zona de liberdade" ao cotidiano das plantations. Assim, ele era uma das únicas atividades totalmente autônomas dos escravos, sendo uma religião e uma força vital proporcionadora de uma liberação psicológica. Habilitava os escravos a expressar e reafirmar sua própria existência que já tinha sido reconhecida através das experiências do trabalho coletivo, do medo e da violência diária. Ou seja, o vodu proporcionava um quadro no qual os escravos conseguiam organizar e direcionar consciências e percepções adquiridas no trabalho e na violência decorrentes da escravidão, agindo como um espaço de reconhecimento mútuo e de diálogo comum de experiências irmãs. Possibilitava, neste sentido, a quebra psicológica das correntes reais e subjetivas da escravidão, tornando os escravos seres independentes, dando-lhes um senso de dignidade e os armando para a sobrevivência e a resistência. Cf.: FICK, Carolyn. The making of Haiti: the Saint Domingue Revolution from below. USA: The University of Tennessee Press, 1990. p. 33-45. Para uma relativização, cf.: GEGGUS, David P. Haitian Revolutionary Studies. USA: Indiana University Press, 2002. p. 74-80; DUBOIS, Laurent. Avengers of the new world: the story of the Haitian Revolution. Harvard: Harvard University Press, 2004, p. 43. 
a língua crioula, ${ }^{79}$ a prática de marronage ${ }^{80} \mathrm{e}$ a violência da escravidão evidenciam um plexo plural de identidades traduzidos em um "movimento exclusivamente transcultural", formado por negros e negras de diferentes regiões e de contextos políticos, sociais e religiosos amplamente diversos. ${ }^{81}$

79 Segundo a historiadora Carolyn Fick, perante a imersão forçada de africanos em um mundo totalmente novo, o encontro e a mistura de culturas fizeram surgir uma língua única e unificadora. Africana na estrutura e no ritmo, mas europeia na dinâmica lexical, teve sua gênese e consolidação no século XVIII, promovendo um quadro linguístico comum de comunicação para diversos grupos de escravos que chegavam a São Domingos. Foi, neste sentido, uma essencial ferramenta unificadora que possibilitou a negros e negras compartilharem experiências, visões de mundo, opiniões e ideias, bem como conspirar contra o sistema FICK, Carolyn. The making of Haiti: the Saint Domingue Revolution from below. USA: The University of Tennessee Press, 1990. p. 40.

80 A marronage, uma espécie de quilombismo, era uma prática de resistência comum a todo o novo mundo e influenciava os escravos de São Domingos de diferentes maneiras. Mesmo sem criar garantias mais profundas, os marrons diziam que o sistema não era inquebrantável e apresentavam-se como saídas reais à submissão. Além disso, estabeleciam relações contingenciais com os escravos que ainda estavam nas plantations, bem como com os livres de cor. $\mathrm{O}$ quadro de possibilidades das práticas de marronage era aprofundado pelas relações estabelecidas com o vodu. Sendo uma forma cultura e uma força político-ideológica potente, advinda de uma grande síntese de religiões, crenças, práticas e tradições africanas que formavam a população negra da colônia, o vodu muitas vezes era praticado pelos líderes dos quilombos, os quais também eram sacerdotes. Essa fusão propiciava a reconstrução de modos de vida africanos na América, por meio da língua, da dança, das cerimônias, da visão de mundo e das curas medicinais. Assim, todo um arcabouço hermenêutico comum era possibilitado, abrindo margem a formação de uma consciência coletiva e de uma identidade independentes dos senhores brancos. Cf.: FICK, Carolyn. The making of Haiti: the Saint Domingue Revolution from below. USA: The University of Tennessee Press, 1990. p. 56-57; DUBOIS, Laurent. Avengers of the new world: the story of the Haitian Revolution. Harvard: Harvard University Press, 2004. p. 55.

81 Como aponta o historiador Laurent Dubois, São Domingos não era majoritariamente composto de escravos, mas sim de africanos, o que recoloca a Revolução Haitiana como precursora das lutas por descolonização africanas. Ele assim coloca a questão: "agora estamos começando a entender que ela foi em si mesma, de diferentes maneiras, uma Revolução Africana”. Cf.: DUBOIS, Laurent. Avengers of the new world: the story of the Haitian Revolution. Harvard: Harvard University Press, 2004. p. 05. Neste aspecto, tornam-se evidentes os deslocamentos e reperiodizações que a Revolução em São Domingos e os desafios do Haiti pós-independência colocam para compreensões historiográficas e filosóficas que tenham em conta a diáspora africana e o Atlântico Negro, como já foi pontuado e será abordado mais adiante.
Influenciada pela Revolução Francesa, que desestabilizaria as relações institucionais e hierárquicas na colônia, em poucos anos os eventos em São Domingos fariam o poder legislativo francês garantir os direitos políticos dos homens livres de cor (1792) e, posteriormente, após a abolição promovida pelos próprios escravos, abolir a escravidão em todas as suas colônias (1794) $)^{82}$. Imporia derrotas aos potentes exércitos espanhol (1795) e inglês (1798), assim como, em seus derradeiros momentos, expulsaria as tropas napoleônicas da ilha quando começavam a retornar os boatos de restauração da escravidão $(1803)^{83}$. Em 1805, a independência seria declarada sob o nome de Haiti, em uma forma de relembrar os primeiros habitantes de São Domingos ${ }^{84}$ e de declarar ao mundo sua oposição à herança colonial-escravocrata do ocidente. ${ }^{85}$

No período pós-revolução, o Haiti, por meio de suas constituições, expressaria uma Modernidade heterogênea diante de um mundo no qual o colonialismo, a escravidão e a "desigualdade entre as raças" eram a norma. Nestes documentos, era possível ver os dilemas, conflitos, interesses e tendências políticas da época, nos quais distinções, tão comuns aos discursos modernos, emergiam no calor dos eventos: universalismo em defesa da igualdade racial contra particularismo de direitos decorrentes de certas especificidades oriundas do colonialismo; ${ }^{86} \mathrm{li}$ -

82 DUBOIS, Laurent. Avengers of the new world: the story of the Haitian revolution. Harvard: Harvard University Press, 2004; GEGGUS, David P. Haitian Revolutionary Studies. USA: Indiana University Press, 2002.

83 JAMES. C. L. R. Os jacobinos negros: Toussaint L'Ouverture e a revolução de São Domingos. Tradução Afonso Teixeira Filho. São Paulo: Boitempo, 2007.

84 O nome "Haiti" era a maneira como os antigos habitantes da ilha, os indígenas taínos, a chamavam . Cf.: DUBOIS, Laurent. Avengers of the new world: the story of the Haitian Revolution. Harvard: Harvard University Press, 2004, p. 299.

85 Para Laurent Dubois, a escolha do nome "Haiti" demonstra uma espécie de política de descolonização avançada dos primeiros líderes haitianos, no sentido de uma "rejeição à falsa filosofia" dos colonizadores brancos e de qualquer tipo de discussão sobre o retorno à escravidão. Cf.: DUBOIS, Laurent. Avengers of the new world: the story of the Haitian Revolution. Harvard: University Press, 2004. p. 299-300. Para uma discussão do nome Haiti enquanto uma mediação de interesses entre as diferentes forças políticas existentes no momento pós-revolucionário, cf.: GEGGUS, David P. Haitian Revolutionary Studies. USA: Indiana University Press, 2002.

86 Um grande exemplo dessa questão está na primeira Constituição pós-independência, de 1805. Logo no seu preâmbulo, fica expresso o tema da igualdade racial, mas expondo uma dialética complicada entre universalismo e particularismo. Afirma-se o princípio da igualdade uni- 
berdade individual versus poder do Estado sobre os indivíduos em decorrência das necessidades econômicas; ${ }^{87}$ e ética internacionalista de combate a escravidão em oposição às restrições nacionalistas para se proteger do imperialismo. ${ }^{88}$

versal e, no mesmo gesto, a diversidade e diferença da humanidade - determina-se a igualdade racial e reconhece o exclusivismo daqueles que foram escravizados. O ápice desse paradoxo é a determinação de que todos os habitantes haitianos devem ser tratados como negros, em uma verdadeira reapropriação da linguagem do colonizador pelo colonizado. Como afirma a filósofa Sibylle Fischer, a adoção dessa linguagem sugere que os revolucionários haitianos começaram pelo significado herdado de um vocabulário pleno de conotações raciais e continuaram por modificá-lo de maneira progressiva, com uma significação de valorização própria das pessoas tidas como negras. $\mathrm{O}$ negro, ali, adquiria o caráter de universalidade contido na categoria cidadão. Cf.: FISCHER, Sibylle. Constituciones haitianas: ideología y cultura posrevolucionarias. Casa de las Américas, La Habana, Cuba, n. 233, p. 18-22, oct./dic. 2003.

87 Para as constituições haitianas, a escravidão nunca foi uma divagação abstrata ou uma metáfora, como costumeiramente ocorria nas discussões constitucionais europeias, muito menos fonte de legitimidade filosófica do Estado. A escravidão era um dado concreto, necessariamente vinculado à experiência moderna e ao colonialismo. É a partir deste ponto que é possível compreender os dispositivos extremamente dirigistas no que toca a organização do trabalho e familiar presentes em algumas das primeiras constituições. Por outro lado, é possível perceber que o mesmo tema da escravidão é trazido para a razão de Estado, em que o Haiti é fundado para garantir a liberdade e acabar com a subordinação racial. Assim, o fim da escravidão não é nem metáfora nem uma lista abstrata de direitos políticos, mas está no programa fundacional do Estado. FISCHER, Sibylle. Constituciones haitianas: ideología y cultura posrevolucionarias. Casa de las Américas, La Habana, Cuba, n. 233, p. 27-31, oct./dic. 2003.

88 O Haiti adotava uma postura de antiescravismo radical, que era um movimento transnacional e transimperial. Ele assim pensava e se colocava dentro da conjuntura internacional. No entanto, do mesmo modo que o universalismo da igualdade racial aparece contraposto ao de uma identidade historicamente modelada, o transnacionalismo antiescravista deverá, eventualmente, confrontar as restrições que os poderes coloniais do momento impunham sobre a política transnacional opositora. As constituições procuraram duas formas de lidar com a questão. A primeira postura foi não regular, de maneira concreta e evidente, as formas de aquisição, definição e naturalização da cidadania haitiana (diferentemente das maneiras clássicas de aquisição sanguínea ou territorial, o Haiti oferecia cidadania para todos os indígenas, africanos e seus descendentes que viessem a residir em seu território - ou seja, todos aqueles que potencialmente pudessem ter sido vítimas da escravidão e do genocídio). A segunda são os artigos que expressam diretamente a política absenteísta do Haiti de não interferir nos assuntos de outros territórios (chegando, inclusive, na Constituição de 1806 a estar no artigo segundo FISCHER, Sibylle. Constituciones haitianas: ide-
Funcionando mais como declarações de independência do que como constituições, as constituições haitianas expressam aspirações e desejos que não podem confinar-se a uma realidade política e social determinada, redesenhavam e rearticulavam o legado da teoria política do iluminismo e da era revolucionária. A concepção de liberdade não se limitava somente à ideia de uma simples “porção de terra”, mas invocava uma nova e radical articulação do conceito de raça e da relação entre liberdade e igualdade ${ }^{89}$. Enquanto as fronteiras dos estados-nação iam restringindo cada vez mais as pretensões universalistas da Modernidade em signos nacionais, étnicos e locais, o Haiti reutilizava os escombros da história ${ }^{90}$ colonial para especializar a cidadania em novas bases. Os haitianos promoveram o fim da escravidão na região, impelindo os Estados europeus a reverem os limites da noção de igualdade, para incluir a igualdade racial ${ }^{91}$.

Enfim, a Revolução do Haiti revela que a "invenção do ser negro escravo"92 pelo colonialismo não era um processo sem contradições. Ela expressava uma reação ao colonialismo que articulou, porém, novas estratégias a partir desse ponto. Dois aspectos interessam especialmente nesse contexto: a consolidação de novas dinâmicas sobre o medo e o surgimento de uma teoria sobre as raças. ${ }^{93}$

O medo é um elemento constitutivo da Modernidade, sendo proporcional à desigualdade que ela instaura

ología y cultura posrevolucionarias. Casa de las Américas, La Habana, Cuba, n. 233, p. 22-27, oct./dic. 2003.

89 FISCHER, Sibylle. Modernity disavowed: Haiti and the cultures of slavery in the age of revolution. USA: Duke University Press, 2004.

90 BENJAMIN, Walter. Sobre o conceito da História. In: BENJAMIN, Walter. O anjo da história. Belo Horizonte: Autêntica, 2013.

91 DUARTE, Evandro C. Do medo da diferença à igualdade como liberdade: as ações afirmativas para negros no ensino superior e os procedimentos de identificação de seus beneficiários. 2011. Tese (Doutorado) - Universidade de Brasília, Brasília, 2011.

92 NADER, Gislene. Direito no Brasil: história e ideologia. In: LYRA, Doreodó Araújo (Org.). Desordem e processo. Porto Alegre: S. A. Fabris, 1986. p. 145-157.

93 Como anotam Elton Batista da Silva e Ana Loryn Soares: "A cultura preservada da África no Haiti funcionou como um elemento homogeneizante, capaz de fornecer as bases de pertencimento e identificação orientadora da luta, o que pode ser percebido, também, através de trechos do Hino Nacional do Haiti, no qual o passado e os ancestrais, base da crença vodu, são evocados: "Pour le pays, pour les ancêtres, Marchons, marchons, marchons unis, Pour le pays, pour les ancêtres [...], Notre passé nous crie [...]". Cf.: SILVA, Elton Batista da; SOARES, Ana Loryn. A Revolução do Haiti: estudo de um caso. Ameríndias, Fortaleza, ano 1, v. 1, p. 01-08, 2006. 
como projeto e realidade. Em regiões em que predominou o sistema de escravidão negra, e especialmente após as revoluções de escravos, os negros passam a ocupar um lugar de destaque no mito moderno ${ }^{94}$. O imaginário do medo de uma revolução escrava (ou um "outro São Domingos" $)^{95}$ foi constituinte das práticas, discursos e estratégias políticas das elites coloniais e da formação dos estados-nação modernos. A Revolução Haitiana demonstrou como a reconstrução cultural dos africanos escravizados nos quadros da diáspora serviu como modo de resistência ao domínio colonial. ${ }^{96}$ Ao mesmo tempo, a liberdade haitiana provocou a defesa de uma forma de pertencimento que não pode ser simplesmente remetida a uma reprodução das identidades culturais dos povos africanos. Embora ela fosse um apelo importante, tratava-se de uma reconstrução, uma invenção, um novo destino comum, uma cultura de novas fronteiras, transatlântica, que deveria saber viver à deriva, sem poder voltar à África ou fugir para a Europa e que, ao mesmo tempo deveria estabelecer pontes entre a África e a América.

A prova do caráter explosivo dessa situação pode ser avaliada pelo esmero como as práticas religiosas dos negros foram retratadas negativamente pela ciência europeia nas décadas subsequentes e, mais particularmente, como o projeto disciplinador escravista valeu-se da religião cristã. Demonizadas e patologizadas, na cultura de massa contemporânea, práticas culturais, como o vodu

94 DUARTE, Evandro C. Do medo da diferença à igualdade como liberdade: as ações afirmativas para negros no ensino superior e os procedimentos de identificação de seus beneficiários. 2011. Tese (Doutorado) - Universidade de Brasília, Brasília, 2011.

95 A historiografia contemporânea dá numerosos eventos das repercussões da Revolução Haitiana no imaginário tanto das elites coloniais, como de negros e negras. Ver, por exemplo: GOMES, Flávio; SOARES, Carlos Eurgênio. Sedições, haitianismo e conexões no Brasil escravista: outras margens do Atlântico Negro. Novos Estudos, São Paulo, n. 63, p. 131-144, 2002; NASCIMENTO, Washington Santos. São Domingos, o grande São Domingos: repercussões e representações da Revolução Haitiana no Brasil escravista (1791-1840). Dimensões, Vitória, v. 21, p. 125-142, 2008; BATISTA, Malaguti Vera. O medo na cidade do Rio de Janeiro: dois tempos de uma história. Rio de Janeiro: Revan, 2003.

96 Como isso se tornou possível? A resposta, proposta por Muniz Sodré, deveria ser buscada na própria estrutura da cultura de várias comunidades africanas de onde os escravos eram trazidos. Quer no uso das tradições cristãs ou na forja de novas manifestações religiosas africanas locais estaria a estrutura da Arké capaz de integrar as contradições. Cf SODRÉ, Muniz. O terreiro e a cidade: a forma social do negro-brasileiro. Petrópolis: Vozes, 1988. p. 97-100. hatiano, mantém-se impregnadas de representações negativas e ao mesmo tempo ameaçadoras. No mesmo passo, contra elas são erguidas um conjunto de estratégias de controle policial e judicial.

Assim, o medo da "onda negra", ou o medo da repetição dos eventos do Haiti, carrega consigo uma transcendência ao gerar questionamentos que devem ser realizados para interpretar todas as áreas afetadas pelo colonialismo: o que esse medo direcionou nas áreas coloniais? Como esse medo criou realidades, hábitos e práticas de dominação e subordinação? Como os medos têm mais impacto sobre nós que as nossas próprias crenças positivas e reivindicações? Além disso, o outro lado da “onda negra" também precisa ser tematizado: em que medida a insurgência negra, uma revolução como a Haitiana, não teria significado mais como uma promessa do que como uma ameaça? Não haveria formas populares e híbridas de produção cultural que escaparam das tentativas de negar e diminuir a resistência negra no Atlântico? Como acessar e narrar a circulação de conhecimentos produzidos pelas lutas diaspóricas no mundo Atlântico através de rumores, músicas e outras expressões? ${ }^{97}$.

Ao se debater o medo, as transformações nas representações dos povos escravizados aparece como questão central, sobretudo, a partir dos acontecimentos no Haiti. Os acontecimentos revolucionários, como demonstrou Susan Buck-Morss, demonstraram que as vítimas da Modernidade poderiam romper com o silêncio do iluminismo europeu diante da escravidão real ${ }^{98}$. As hierarquias sociais não eram mais facilmente aceitas, pois os negros enterraram a ideia de que a escravidão era uma opção viável para a organização econômica e seu destino "natural". As ideias iluministas se propagavam com a escravidão sem, contudo, submeterem-se ao controle de significados desejado pelas elites locais que silenciavam sobre a escravidão negra ou a consideravam legítima por ser uma dimensão da propriedade. As imagens sobre as resistências escravas e o destino da escravidão com os processos de independência das colônias foram, no mesmo passo, decisivas para construir e delimitar o problema da forma constitucional, e, sobretudo, da concepção de povo na construção de direitos. Muitos do movimentos

97 FISCHER, Sibylle. Modernity disavowed: Haiti and the cultures of slavery in the age of revolution. USA: Duke University Press, 2004.

98 BUCK-MORSS, Susan. Haiti, and universal history. USA: University of Pitssburgh Press, 2009. 
de independência na América Latina foram construídos com e contra revoltas de negros escravizados.

Por certo que os sentidos sociais da ação dessas revoltas variaram no desenrolar dos acontecimentos que se passavam nos EUA e na França em relação a múltiplos aspectos, como por exemplo, a existência de fraturas entre as elites provocadas no curso da ruptura do pacto colonial, a construção de redes de comunicação, o uso ambíguo do espaço urbano, as consequências para o cotidiano do trabalho das novas necessidades de produção, a eficiência das formas de controle social que foram sendo implantadas etc. Porém, o que unifica tais revoltas no curso do século XIX é a representação crescente de uma elite e de uma sociedade, dependentes do trabalho escravo, que se sentiam ameaçadas.

As revoluções escravas fizeram "parte integrante dos movimentos revolucionários burgueses-democráticos internacionais". Elas sugerem uma alternativa as visões do escravo como vítima passiva da opressão escravista e a do escravo como consciência alienada, incapaz de se articular politicamente $e^{99100}$. Isso não significa que todo ato de violência individual ou coletivo, a partir da "era das revoluções" fossem marcados pela consciência dos escravos da necessidade de transformar o conjunto da sociedade, mas que, no mínimo, esse passou a ser o campo de compreensão desses atos de violência por parte de seus senhores que, mesmo acreditando na inferioridade natural de seus escravos não podiam mais aceitar como certa a sua inferioridade bélica. As hierarquias transportadas para fora do espaço da Europa, mas promovidas pela burguesia, também estavam em crise. A "era das revoluções" provoca, no mínimo, a certeza de que a escravidão perpetuava, por outros meios, a guerra de uma grande massa contra uma minoria de privilegiados. ${ }^{101}$

99 GENOVESE, Eugene Dominick. Da rebelião à revolução: as revoltas de escravos negros nas Américas. São Paulo: Global, 1983. p. 14.

100 Embora, como se verá adiante, a política e as praticas culturais não se apresentem assim tão dissociadas.

101 A situação já estava se transformando mesmo antes da eclosão da Revolução de São Domingos: "Os mundos coloniais americanos foram regularmente abalados pelas revoltas dos seus escravos, ou por ameaças de revoltas. Os administradores das colónias inglesas e francesas das Caraíbas reconheciam, nos anos 1730 , que "um vento libertário" soprava nas Caraíbas indicando assim a existência de um verdadeiro contágio dos fenómenos de resistência à escravidão, como ocorreu, meio século mais tarde, por ocasião da rebelião dos escravos de Saint-Domingue.. Cf.: STENOU, Katerina. Lutas contra a escravidão; Ano Internacional de luta contra a escravidão e de sua abolição -
A interdependência econômica existente no colonialismo e a dependência da escravidão produzem não apenas um fluxo de ideias de múltiplas direções quanto um delicado jogo de possibilidades entre liberdade e escravidão. Basta imaginar, como sugere Eugene Genovese, os diferentes destinos que a Revolução Francesa poderia ter tido se constasse com a maquinaria colonial, como fez Napoleão. A escravidão negra não estava na periferia, mas no centro dos acontecimentos políticos da "era das revoluções" e, portanto, de suas contradições ${ }^{102}$.

Arthur Gobineau, amigo de D. Pedro II, muitas vezes apresentado como o poço envenenado donde brotou toda a teoria racista, sintetiza os deslocamentos das representações sobre os escravizados, a construção discurso sobre a raça e o papel ocupado por teorias sobre o "confronto de civilizações". O pensamento de Arthur Gobineau emerge do entrave do paradigma ocidental da Modernidade que apontava a um só tempo para o particularismo, contido no silêncio diante da escravidão somado a um sentimento generalizado de superioridade europeu, e a universalização da igualdade e da liberdade imposta pelos Jacobinos Negros. Em seu "Ensaio sobre a desigualdade das raças", o autor defende que a igualdade jurídica, conquistada pelos negros na Revolução do Haiti, não poderia resolver o problema de sua "desigualdade natural", pensada agora a partir de uma teoria das raças ${ }^{103}$.

Após 1791, conceber o Republicanismo como uma matriz universal era tolerar a quebra nas hierarquias do poder mundial eurocêntrico. Tratava-se de tolerar a possibilidade de burocracias locais mediadas por uma estrutura jurídica que estivesse fundada na auto-determinação individual e coletiva de grupos sociais que antes haviam sido arrastados à condição de escravidão ou submissão. Gobineau, então, propõe, a partir das teoria racial que se organiza justamente na virada no século XVIII para o XIX, refletir sobre a construção de novas nacionalidades que fossem compatíveis com tais hierar-

2004. Paris: UNESCO, 2004. Disponível em: <http://www. unesco.org/culture>. Acesso em: 05 nov. 2016. p. 48.

102 GENOVESE, Eugene Dominick. Da rebelião à revolução: as revoltas de escravos negros nas Américas. São Paulo: Global, 1983.

103 DUARTE, Evandro C. Do medo da diferença à igualdade como liberdade: as ações afirmativas para negros no ensino superior e os procedimentos de identificação de seus beneficiários. 2011. Tese (Doutorado) - Universidade de Brasília, Brasília, 2011. p. 567 e ss.; GOBINEAU, Arthur. Essai sur l'inégalité des races humaines. Paris: Éditions Pierre Belfond, 1967. p. 77. 
quias (no plano das relações entre as nações europeias e estrangeiras e no interior das novas nações). Ou seja, a teoria da raça permitiu que o autor afirmasse a diferença como fundamento da desigualdade num mundo em que as hierarquias naturalizadas estavam sendo corroídas pelas disputas políticas revolucionárias articuladas a partir de uma gramática de direitos. Isso significa que, do seu ponto de vista, os africanos escravizados e os povos originários seriam incompatíveis com a República, ou melhor, nos trópicos, ela somente seria possível com o domínio dos brancos sobre os demais grupos. ${ }^{104}$

Sua obra representou uma reação contra a possibilidade de integrar a diversidade humana subjacente à Conquista num modelo Republicano. Gobineau defendeu a diferença mais do que ninguém. Os negros somente poderiam viver sob formas tribais ou regimes autoritários. O Republicanismo era um atributo da raça branca. A diferença racial impunha a marca da percepção ocidental desde a estética, passando pela formas de organização política, até a linguagem utilizada pelos não-europeus. De igual modo, se os não-europeus assumiam o modelo Republicano estariam apenas a «macaquear» a forma, sem apreender o conteúdo. A forma constitucional não poderia sobreviver sem um conteúdo determinado, o substrato cultural dos grupos raciais desenvolvidos. Portanto, a teoria racial embranqueceu a memória do constitucionalismo, apagando e minimizando as disputas ocorridas no Atlântico Negro ${ }^{105}$.

Como se percebe nas teorias de Gobineau, a construção da nacionalidade (ou da sua impossibilidade como princípio unitário e abstrato) dos "locais" foi o modo mais adequado para que a teoria política do século XIX pudesse pensar a clausura da diferença e a submissão da diversidade humana. A inadequação das instituições não se referia ao fato de que elas não representavam a vontade democrática, calcada na Igualdade e na Liberdade, mas que tais instituições não poderiam ser democráticas por culpa do povo (ou de uma parte dele) e porque não eram capazes de controlar a "natureza" desse povo. O elemento

104 DUARTE, Evandro C. Do medo da diferença à igualdade como liberdade: as ações afirmativas para negros no ensino superior e os procedimentos de identificação de seus beneficiários. 2011. Tese (Doutorado) - Universidade de Brasília, Brasília, 2011. p. 566.

105 DUARTE, Evandro C. Do medo da diferença à igualdade como liberdade: as ações afirmativas para negros no ensino superior e os procedimentos de identificação de seus beneficiários. 2011. Tese (Doutorado) - Universidade de Brasília, Brasília, 2011. p. 556. "povo" foi a desculpa da arquitetura conservadora do Estado Autoritário para esse "resto do mundo". Ao mesmo tempo, a diversidade foi o outro elemento que acompanhou as preocupações de gerenciamento autoritário do Estado. A diversidade tolerada não poderia estabelecer um vínculo com a política e deveria ser funcional ao sistema econômico ${ }^{106}$.

Em síntese, a teoria das raças foi gestada numa conjuntura em que a própria ideia de hierarquia racial havia sido questionada e duramente atacada por novas formas de hibridismo cultural, por ressignificações e redefinições das teorias políticas europeias sobre igualdade e liberdade. A teoria das raças, portanto, não criou as hierarquias raciais do colonialismo, ao invés disso, organizou sua defesa como teoria política referente à nacionalidade e à cidadania, tornando-se a matriz do Estado Autoritário nos novos países independentes; orientou o Imperialismo dos países centrais e a aliança com as elites locais; e, ao mesmo tempo, especializou-se como discurso sobre o controle social, ou seja, deu origem à Criminologia, como tratamos no outro capítulo.. De forma difusa, ou localizada, estava o medo da Revolução, e especialmente, o medo de que a gramática dos direitos pudesse ser reconstruída por vozes múltiplas para além das fronteiras e das hierarquias do colonialismo e do Estado Nacional ${ }^{107}$.

\section{Biopoder, racismo, conquista e colonialida- de: notas sobre Foucault e Agamben}

De que modo, a historiografia utilizada pela Criminologia Crítica pensou esses eventos relacionados à Modernidade e ao surgimento do racismo? Michel Foucault foi quem mais se deteve sobre o tema do racismo. $\mathrm{O}$ autor trata do "poder de morte" e do "poder sobre a vida" como um par conceitual que estrutura aquilo que ele entende por "biopoder" e que marca uma transformação profunda dos mecanismos de poder. De uma época clássica, em que era exercido sob a forma de "confisco" (apreensão das coisas, do tempo, dos corpos e da vida),

106 DUARTE, Evandro C. Do medo da diferença à igualdade como liberdade: as ações afirmativas para negros no ensino superior e os procedimentos de identificação de seus beneficiários. 2011. Tese (Doutorado) - Universidade de Brasília, Brasília, 2011. p. 571.

107 DUARTE, Evandro C. Do medo da diferença à igualdade como liberdade: as ações afirmativas para negros no ensino superior e os procedimentos de identificação de seus beneficiários. 2011. Tese (Doutorado) - Universidade de Brasília, Brasília, 2011. p. 570. 
para o período moderno, no qual o confisco passa a ser apenas uma das "peças" 108 desse poder, que agora "se situa e exerce ao nível da vida, da espécie, da raça e dos fenômenos maciços de população"109. Esse "poder de morte", antes mencionado, desloca-se e passa a se apoiar não mais em um poder que se apropria da vida para suprimi-la, mas que a gerencia, promove sua majoração, sua multiplicação.

Foucault está envolvido em uma reinterpretação teórica daquilo que se entende por "poder": fora, portanto, do modelo de análise proposto pela soberania jurídica e pela instituição estatal, ou antes, "fora do modelo do Leviatâ" ${ }^{\prime 11}$. Para tal, é necessário adotar uma postura metódica orientada não para o "edifício jurídico da soberania”"111, mas para os processos materiais de dominação, para os mecanismos de sujeição da vida.

Foi essa reorientação metódica que levou Foucault a se voltar para o fenômeno da "raça", ou mais especificamente, para a "guerra entre as raças". Esta última funcionaria como uma "contra-história"112, que é justamente o que introduz o modelo da guerra para se pensar a história $^{113}$. Com isso, o poder político deixa de ser visto como o momento de pacificação social e passa, ao contrário, a ver a guerra em sua própria origem: "A organização, a es-

108 FOUCAULT, Michel. Em defesa da sociedade. Trad.: Maria Ermantina Galvão. São Paulo: M. Fontes, 1999. p. 128.

109 FOUCAULT, Michel. Em defesa da sociedade. Trad.: Maria Ermantina Galvão. São Paulo: M. Fontes, 1999. p. 129.

110 FOUCAULT, Michel. Em defesa da sociedade. Trad.: Maria Ermantina Galvão. São Paulo: M. Fontes, 1999. p. 40.

111 FOUCAULT, Michel. Em defesa da sociedade. Trad.: Maria Ermantina Galvão. São Paulo: M. Fontes, 1999. p. 40.

112 A ideia de uma "contra-história", como explica Tomás Abraham no prefácio da edição castelhana de "Em defesa da sociedade" (Genealogía del racismo), é aquela envolvida em uma subversão da história sustentada sobre as concepções jurídico-filosóficas do contrato. Trata-se daquilo que Foucault chama de certo "economismo" na teoria do poder, que o concebe como um direito que se adquire como um "bem" e que pode ser "transferido" ou mesmo "alienado". Cf.: FOUCAULT, Michel. Em defesa da sociedade. Trad.: Maria Ermantina Galvão. São Paulo: M. Fontes, 1999. p. 19 e ss.

Para a perspectiva metodológica da contra-história, a verdade não estaria apartada do conflito, mas, ao contrário, surgiria a partir dele. Cf.: FOUCAULT, Michel. Genealogía del racismo. Buenos Aires: Altamira, 1976. p. 07 e ss.

113 Ou como ele coloca na "Terceira Conferência" de 21 de janeiro de 1976: "E essa discurso histórico-político que aparece nesse momento é, ao mesmo tempo, um discurso sobre a guerra entendida como relação social permanente, como fundamento indelével de todas as relações e de todas as instituições de poder". Cf.: FOUCAULT, Michel. Em defesa da sociedade. Trad.: Maria Ermantina Galvão. São Paulo: M. Fontes, 1999. p. 56. trutura jurídica do poder, dos Estados, das monarquias, das sociedades, não têm seu princípio no ponto em que cessa o ruído das armas. A guerra não é conjurada"114. A contra-história do discurso sobre a raça é o que permite romper com o modelo "jupiteriano" da historiografia tradicional, "[...] uma história da soberania, uma história que se desenvolve na dimensão e na função da soberania"115.

Para Foucault, entretanto, o sentido desta "guerra das raças" sofre uma importante mudança e adquire um sentido biológico ${ }^{116}$, com os contornos do evolucionismo e das teorias da degeneração dos fisiólogos. O próprio autor esclarece, entretanto, em determinado momento, que esse discurso da luta das raças é marcado por certa "polivalência estratégica" ${ }^{\prime 17}$ desde o princípio. É um discurso das oposições, de grande circulação entre os diferentes grupos, servindo como "[...] instrumento de crítica e de luta contra uma forma de poder [...]" e que foi veiculado tanto como um projeto pós-revolucionário de escrever uma história centrada no "povo" enquanto categoria fundamental quanto como instrumento de "[...] desqualificação das sub-raças colonizadas" ${ }^{\prime 18}$.

É em momento posterior, contudo, que o discurso da luta das raças passa por duas "transcrições", analisadas por ele a partir da Revolução Francesa: de um lado, uma transcrição biológica, que ocorre antes de Darwin e que se apropria de seu discurso (nascimento de uma teoria das raças no sentido histórico-biológico do termo); de outro, que tenderá a apagar todos os vestígios do conflito de raças e se transforma em luta de classe ${ }^{119}$. A partir daí o autor localiza um racismo biológico-social, não mais estruturado sob o enfrentamento entre duas raças exte-

114 FOUCAULT, Michel. Em defesa da sociedade. Trad.: Maria Ermantina Galvão. São Paulo: M. Fontes, 1999. p. 58.

115 FOUCAULT, Michel. Em defesa da sociedade. Trad.: Maria Ermantina Galvão. São Paulo: M. Fontes, 1999. p. 79.

116 Foucault, entretanto, chama a atenção, em determinado momento, de certo sentido "polivalente" do discurso da luta das raças. Tratava-se, desde o princípio, de um discurso ambivalente, dotado de "uma espécie de polivalência estratégica". É um discurso de grande circulação, um "discurso das oposições, dos diferentes grupos de oposição". Cf.: FOUCAULT, Michel. Em defesa da sociedade. Trad.: Maria Ermantina Galvão. São Paulo: M. Fontes, 1999. p. 89.

117 FOUCAULT, Michel. Em defesa da sociedade. Trad.: Maria Ermantina Galvão. São Paulo: M. Fontes, 1999. p. 89.

118 FOUCAULT, Michel. Em defesa da sociedade. Trad.: Maria Ermantina Galvão. São Paulo: M. Fontes, 1999. p. 89.

119 FOUCAULT, Michel. Em defesa da sociedade. Trad.: Maria Ermantina Galvão. São Paulo: M. Fontes, 1999. p. 71 e ss. 
riores uma à outra, mas como o desdobramento de uma mesma raça, dividida em uma super-raça e uma sub-raça. Como ele coloca:

\begin{abstract}
[...] esse discurso da luta das raças - que, no momento em que apareceu e começou a funcionar no século XVII, era essencialmente um instrumento de luta para campos descentralizados - vai ser recentralizado e tornar-se justamente o discurso do poder, de um poder centrado, centralizado e centralizador; o discurso de um combate que deve ser travado não entre duas raças, mas a partir de uma raça considerada como sendo a verdadeira e a única, aquela que detém o poder e aquela que é titular da norma, contra aqueles que estão fora dessa norma, contra aqueles que constituem outros tantos perigos para o patrimônio biológico ${ }^{120}$
\end{abstract}

Nesse momento, o discurso racista adquire para o autor a forma de um racismo de Estado, exercido não mais como um mecanismo de defesa da sociedade contra uma "raça vinda do exterior", mas que ela exercerá sobre ela própria, um "racismo interno" em relação a seus próprios elementos, "[...] o da purificação permanente, que será uma das dimensões fundamentais da normalização social"121. Esse é o momento em que Foucault marca, explicitamente, o "surgimento" do racismo, guardando conexões importantes, inclusive, com o "discurso revolucionário": "Quando o tema da pureza da raça toma o lugar do da luta das raças, eu acho que nasce o racismo, ou que está se operando a conversão da contra-história em um racismo biológico"122.

Esse poder sobre a vida e sobre a morte de que fala Foucault é retomado por Agamben em O que resta de Auschwitz para também situá-lo no contexto do "racismo de Estado". Para Agamben, as categorias "fazer viver" e "deixar morrer", com que Foucault interpreta a mudança dos mecanismos de poder de uma concepção clássica para a forma moderna, passam por um processo de absolutização, que coloca no debate um aparente paradoxo, que é o mesmo lançado pelo pensador francês ${ }^{123}$ : "Como

120 FOUCAULT, Michel. Em defesa da sociedade. Trad.: Maria Ermantina Galvão. São Paulo: M. Fontes, 1999. p. 72-73.

121 FOUCAULT, Michel. Em defesa da sociedade. Trad.: Maria Ermantina Galvão. São Paulo: M. Fontes, 1999. p. 73.

122 FOUCAULT, Michel. Em defesa da sociedade. Trad.: Maria Ermantina Galvão. São Paulo: M. Fontes, 1999. p. 95.

123 O paradoxo é enunciado por Foucault na aula de 17 de março de 1976, reunida em "Em defesa da Sociedade": "Como um poder como este poder matar, se é verdade que se trata essencialmente de aumentar a vida, de prolongar sua duração, de multiplicar suas possibilidades, [...]? [...] Como esse poder que tem essencialmente o objetivo de fazer viver pode deixar morrer? [...]". Cf.: FOUCAULT, é possível que um poder cujo objetivo é essencialmente o de fazer viver exerça por sua vez um incondicionado poder de morte?"124. A resposta a esse aparente paradoxo é dada pelo racismo. Embora o racismo já existisse ${ }^{125}$, é nesse momento, segundo Foucault seguido também por Agamben, que ele se insere nos mecanismos do Estado: Foi nesse momento que o racismo se inseriu como mecanismo fundamental do poder, tal como se exerce nos Estados modernos, e que faz com que quase não haja funcionamento moderno do Estado que, em certo momento, em certo limite e em certas condições, não passe pelo racismo ${ }^{126}$.

O racismo é o que fragmenta o domínio do campo biológico, permitindo distinguir entre o que deve viver e o que deve morrer. Em outras palavras, "a raça, o racismo, é a condição de aceitabilidade de tirar a vida numa sociedade de normalização"127.

Para Agamben, por sua vez, o campo de concentração representa o espaço em que as cesuras biopolíticas atingem seu limite. Esse limite é aquilo que ele chama de "muçulmano" (Muselmann). Trata-se da denominação dada ao prisioneiro na linguagem do Lager, o morto-vivo que, por ter sido privado de qualquer dignidade ${ }^{128}$, flutua entre a vida e a morte, entre o humano e o inumano. O objetivo maior do biopoder é produzir essa separação permanente entre o não-homem e o homem; não um poder que "faz viver" ou "faz morrer", mas "faz sobreviver", enquanto uma espécie de terceiro estado da biopolítica inaugurado por Auschwitz: "Nem a vida nem a morte,

Michel. Em defesa da sociedade. Trad.: Maria Ermantina Galvão. São Paulo: M. Fontes, 1999. p. 304.

124 AGAMBEN, Giorgio. O que resta de Auschwitz: o arquivo e a testemunha (Homo Sacer III). Trad. Selvino J. Assmann. São Paulo: Boitempo, 2008. p. 89.

125 Sobre esse ponto, Foucault esclarece: "É aí, creio eu, que intervém o racismo. Não quero de modo algum dizer que o racismo foi inventado nessa época. Ele existia há muito tempo. Mas eu acho que funcionava de outro modo". Cf.: FOUCAULT, Michel. Em defesa da sociedade. Trad.: Maria Ermantina Galvão. São Paulo: M. Fontes, 1999. p. 304.

126 FOUCAULT, Michel. Em defesa da sociedade. Trad.: Maria Ermantina Galvão. São Paulo: M. Fontes, 1999. p. 304.

127 FOUCAULT, Michel. Em defesa da sociedade. Trad.: Maria Ermantina Galvão. São Paulo: M. Fontes, 1999. p. 306.

128 Como ele explica: “Também os nazistas recorrem, com referência à condição jurídica dos judeus depois das leis marciais, a um termo que implica a dignidade: entwürdigen. O judeu é o homem que foi privado de qualquer Würde, de qualquer dignidade: apenas homem - e precisamente por isso, não-homem". Cf.: AGAMBEN, Giorgio. O que resta de Auschwitz: o arquivo e a testemunha (Homo Sacer III). Trad. Selvino J. Assmann. São Paulo: Boitempo, 2008. p. 75. 
mas a produção de uma sobrevivência modulável virtualmente infinita constitui a tarefa decisiva do biopoder do nosso tempo"129. Seguindo Foucault e Agamben, portanto, é possível dizer que o racismo é o que permite matar sem que ocorra qualquer punição, é a condição de aceitação da matança, ou antes, a condição de possibilidade da vida "matável e insacrificável" do homo sacer" ${ }^{130}$.

Embora racismo e biopolítica sejam articulados por Foucault e por Agamben como faces de um mesmo fenômeno, tais conceitos ainda são pensados sob bases histórico-filosóficas insuficientes. Ao delimitar o racismo enquanto "racismo de Estado", ambos acabam por limitar tal fenômeno ao experimentado pela Europa no século XX. O conceito de "racismo" tanto para um quanto para o outro é insuficiente por se mostrar incapaz de pensar desde a Conquista. E “Conquista” entendida não apenas enquanto evento histórico passado, mas, sobretudo, como "ordem conceitual"131 inaugurada a partir da tomada de terra. Categorias como "racismo", "biopolítica" e "estado de exceção" precisam ser articuladas tendo como horizonte a dominação colonial. $\mathrm{O}$ próprio vínculo entre $\mathrm{o}$ “estado de exceção" e "conquista”, desenvolvido por um autor como Carl Schmitt ${ }^{132}$, é omitido por Agamben, a

129 AGAMBEN, Giorgio. O que resta de Auschwitz: o arquivo e a testemunha (Homo Sacer III). Trad. Selvino J. Assmann. São Paulo: Boitempo, 2008. p. 155.

130 A vida "matável e insacrificável" do homo sacer é a fórmula empregada por Agamben para definir o conceito de "vida nua". Sobre isso, cf.: AGAMBEN, G. Homo Sacer: o poder soberano e a vida nua I. Trad. Henrique Burigo. Belo Horizonte: UFMG, 2010. p. 16. O "homo sacer" é uma figura do direito arcaico romano retomada por Agamben por representar o primeiro momento em que a ideia de sacralidade se aproxima da vida humana enquanto tal. Assim: AGAMBEN, G. Homo Sacer: o poder soberano e a vida nua I. Trad. Henrique Burigo. Belo Horizonte: UFMG, 2010. p. 74. A "vida nua" do homem sacro marca justamente o ponto de indistinção abordado: "Nem bios político nem zoé natural, a vida sacra é a zona de indistinção na qual, implicando-se e excluindo-se um ao outro, estes se constituem mutuamente". Cf.: AGAMBEN, G. Homo Sacer: o poder soberano e a vida nua I. Trad. Henrique Burigo. Belo Horizonte: UFMG, 2010. p. 91.

131 Pedro Argolo, em monografia intitulada "Entre Hidra e Leviatã: o Nomos da Terra de Carl Schmitt e o paradoxo da história universal", retomando o conceito de "Nomos da Terra" de Carl Schmitt, fala em um "Nomos da Conquista" para mostrar de que maneira a "aparição do Novo Mundo" atuou "[...] na reorganização do espaço e de todo um sistema de pensamento a partir do século XVI". Cf.: COSTA, Pedro Henrique Argolo. Entre hidra e leviatã: o nomos da terra de Carl Schmitt e o paradoxo da história universal. 2016. TCC (Monografia em Direito) - Universidade de Brasília, Brasília, 2015. p. 12.

132 Ao comentar a nova ordenação do espaço surgida no despeito da obra deste último retomar várias das ideias desenvolvidas por aquele.

De toda sorte, apresentado o percurso foucaultiano, a mimese acadêmica nos levaria a um mesmo lugar: transpor para o momento presente as categorias do autor. Todavia, dois elementos chamam a atenção. A teoria da soberania jurídica serviu para explicar o conceito de poder das teorias penais e também das teorias sobre a escravidão. O poder encontra-se na possibilidade de um sujeito obrigar outro sujeito a fazer, ou deixar de fazer algo, em virtude do exercício da força física, mediante, quase sempre, de uma superioridade de força física ou de um uso de um instrumento. Assim, o lado de fora, o lado da liberdade, estaria na ausência dessa coação. Submeter-se à força é ceder sua liberdade. Desse modo, a submissão do escravo repousa no fato de que ele é a presa de guerra, e o domínio sobre seu ser dependeria da presença da espada sobre sua cabeça. Rousseau, em O contrato social ou Princípios do Direito Político ${ }^{133}$, atribui a Grotius tal concepção da escravidão: para este último a guerra estava na origem do pretenso "direito de escravidão"134. Uma vez

século XVI com o Nomos da Conquista, Carl Schmitt faz menção a dois "espaços de liberdade": "O primeiro é a América, enquanto solo a ser apropriado; um 'espaço ilimitado de terra livre', ou antes, 'Land der Freiheit', uma terra da liberdade. O segundo, por sua vez, corresponde ao mar, que vai compor um binômio relevante para a maneira com que Schmitt compreende a organização do espaço: terra firme, enquanto propriamente território estatal, e mar livre". Assim: COSTA, Pedro Henrique Argolo. Entre hidra e leviatã: o nomos da terra de Carl Schmitt e o paradoxo da história universal. 2016. TCC (Monografia em Direito) - Universidade de Brasília, Brasília, 2015. p. 24. A relação entre esses "espaços de liberdade" e o conceito de "estado de exceção" é próxima ao ponto de Schmitt tratar como semelhantes a "Martial Law" inglesa e "e a ideia de um espaço delimitado, livre e vazio, que se apresenta na produção dos territórios 'livres' à época da Conquista. Noção essa que integra também o conceito de 'campo' que Agamben deseja propor”. Sobre isso, cf.: COSTA, Pedro Henrique Argolo. Entre hidra e leviatã: o nomos da terra de Carl Schmitt e o paradoxo da história universal. 2016. TCC (Monografia em Direito) - Universidade de Brasília, Brasília, 2015. p. 49. De igual modo, aproximasse das explicações de Hanna Arendt sobre o nascimento do racismo. Cf.: ARENDT, Hannah. Origens do totalitarismo. Trad. Roberto Raposo. São Paulo: Companhia das Letras, 2012.

133 ROUSSEAU, Jean-Jacques. O contrato social: princípios do direito político. Trad: Antonio de Pádua Danesi. São Paulo: M. Fontes, 1996. p. 13 e ss.

134 Para Rousseau, entretanto, havia uma incompatibilidade radical entre direito e escravidão, desenvolvida pelo autor no "capítulo IV" da "Parte I" do citado livro: "seja qual for o lado por que se considerem as coisas, o direito de escravizar é nulo, não somente porque é ilegítimo, mas 
que o vencedor teria o direito de matar o vencido, aquele poderia "resgatar sua vida" em troca de sua liberdade: a escravidão resultaria, portanto, desse pretenso direito de matar garantido pelo estado de guerra.

Já um autor como Hegel, por sua vez, malgrado sua construção sobre a dimensão intersubjetiva do reconhecimento, ao afirmar que entre o par "senhor-escravo" haveria uma luta de vida e de morte, faz repousar sobre a relação individual "senhor-escravo", ou seja, na coação de um sobre outro, a essência da escravidão. A escravidão, portanto, não aparece nessas perspectiva numa dimensão social em que a essência é a administração da vida e da morte de forma coletiva. Reforça tal interpretação a própria diferença de tratamento dado por Hegel ao problema do reconhecimento na Fenomenologia e a apresentada tanto na Filosofia do Espírito (1805), quanto na Enciclopédia (1830). Nestes últimos trabalhos, como esclarece Vladimir Safatle na aula 14/30 de seu Curso Integral - A fenomenologia do Espírito, o reconhecimento é tratado a partir dos conceitos de crime, bens, lei e constituição ${ }^{135}$. $\mathrm{Na}$ Fenomenologia, ao contrário, Hegel está envolvido na questão da universalidade, em que os problemas políticos não desaparecem, mas surgem reconectados pelas "figuras da consciência"136.

porque absurdo e sem significação. As palavras escravidão e direito são contraditórias; excluem-se mutuamente". Cf.: ROUSSEAU, Jean-Jacques. O contrato social: princípios do direito político. Trad: Antonio de Pádua Danesi. São Paulo: M. Fontes, 1996. p. 18. Susan Buck-Morss, por sua vez, a partir do filósofo catalão Louis Sala-Molins, critica a total omissão de Rousseau em relação ao Code Noir e aos "milhões de escravos realmente existentes sob o jugo de senhores europeus". Cf.: BUCK-MORSS, Susan. Hegel, Haiti, and universal history. Pitssburgh: University of Pitssburgh Press, 2009. p. 136.

135 SAFATLE, Vladimir. Curso integral: A Fenomenologia do Espírito, de Hegel. Brasil, 2007. Disponível em: <https:// www.academia.edu/5857053/Curso_Integral_-_A_Fenomenologia_do_Esp\%C3\%ADrito_de_Hegel_2007_>. Acesso em: 05 nov. 2016. p. 06.

136 Não por acaso, a "dialética do Senhor e do Escravo" aparece na parte intitulada "Consciência-de-si" da Fenomenologia. Ao final do $\$ 189$, Hegel, ao se referir ao Senhor e ao Escravo, diz que "[...] os dois momentos são como duas figuras opostas da consciência: uma, a consciência independente para a qual o ser-para-si é a essência; outra, a consciência dependente para a qual a essência é a vida, ou um ser para o Outro. Uma é o senhor, outra é o escravo". Cf.: HEGEL Georg Wilhelm Friedrich. Fenomenologia do espírito. Rio de Janeiro: Vozes, 2012. p. 147. Safatle chama a atenção para a ambiguidade desse trecho: o "como se" hegeliano permite interpretar Senhor e Escravo tanto como a exteriorização de uma divisão interna da consciência, quanto "o resultado de uma confrontação entre duas consciências-de-si independentes em um movimen-
O pano de fundo implícito da visão da escravidão no pensamento hegemônico e contra-hegemônico de tradição hegeliana identifica a relação senhor escravo na violência pura, ocultando até mesmo a dimensão de condicionamento da subjetividade do senhor encontrada em Hegel. A escravidão é representada, no mais das vezes, na fórmula marxista da coação direta, pela oposição clássica do iluminismo entre coação (opressão) e consenso (liberdade) e para qual parece existir somente uma outra alternativa, a imagem da "escravidão contrato cotidiano" que tem sido erguida pelo revisionismo histórico para fazer da escravidão um palco de curiosidades ao gosto das elites brancas coloniais ${ }^{137}$. Muito embora herdeiros da crítica à noção de sujeito e da liberdade supostamente existente no consenso, Michel Foucault e Agamben, ao darem as costas para a complexidade do escravismo, aceitam uma visão clássica da submissão pela coação, pura, direta, e porque não dizer, simples. Acreditam e reproduzem momentos geracionais das estratégias de poder na Modernidade que estão distantes das novas narrativas contra-hegemônicas, produzidas pela crítica pós-colonial e do pensamento negro. Falta-lhes, portanto, a imagem da escravidão como processo histórico, momento geracional da burocracia e do mercado, espaço de criação e experimentação das formas modernas de domínio ${ }^{138}$.

to fundador dos processos de interação social" SAFATLE, Vladimir. Curso integral: A Fenomenologia do Espírito, de Hegel. Brasil, 2007. Disponível em: <https://www.academia.edu/5857053/Curso_Integral_-_A_Fenomenologia_do_Esp\%C3\%ADrito_de_Hegel_2007_>. Acesso em 05 nov. 2016. p. 05.

137 Jacob Gorender menciona a mudança operada pelo revisionismo que passa a ressaltar o escravo como "ser autônomo", agente dotado de vontade própria, como um recurso propriamente ideológico. Assim explica: "Mas, se a historiografia brasileira pretensamente nova quis recuperar a subjetividade autônoma do escravo, não o fez para destacar as reações anti-sistêmicas, como os levantes, quilombos, atentados e fugas. Ao contrário, subiram ao primeiro plano as estratégias (sic) cotidianas e suaves de acomodação do escravo ao sistema escravocrata. Recuperou-se a subjetividade do escravo para fazê-lo agente voluntário da reconciliação com a escravidão". Cf.: GORENDER, Jacob. A escravidão reabilitada. São Paulo: Ática, 1990. p. 20.

138 A relação entre a gestação da "raça" e da "burocracia" em meio ao processo de dominação colonial é desenvolvida por Hanna Arendt em Origens do Totalitarismo, que os apresenta como "Dois novos mecanismos de organização política e de domínio dos povos estrangeiros". E continua: "Sem a raça para substituir a nação, a corrida para a África e a febre dos investimentos poderiam ter -se reduzido para usar a expressão de Joseph Conrad - à desnorteada 'dança da morte e do comércio' das corridas do ouro. Sem a burocracia para substituir o governo, a possessão britâ- 
Quando se consideram períodos históricos mais longos e outras "margens" além dos estreitos limites do Estado Nacional dos países centrais, percebe-se que as categorias compreensivas ali produzidas são mais do que meramente insuficientes. Elas não padecem apenas de um vício de parcialidade. Não dão apenas visões particulares alçadas à condição de universais. São parciais porque não foram capazes de estabelecer relações com outros particulares constitutivos de sua definição. Não se pode afirmar que há uma história europeia que desconsiderou a história dos povos do "resto do mundo". O antídoto não pode ser a soma de duas parcialidades, pois não há história europeia sem se fazer a história darelação constitutiva dessa região com outras regiões do mundo. O "resto do mundo" está dentro da "Europa" e vice-versa.

O mesmo raciocínio vale para grupos sociais que tiveram sua memória normatizada pela história do Estado Nacional. Não basta buscar, agora, uma história dos excluídos. É preciso inscrever a história do excluídos da historiografia oficial nas lutas sociais ao longo da história e das estratégias de apagamento da memória coletiva. Incluí-los como negatividade e como positividade dessa história do poder.

É esse pensamento orientado pelo reconhecimento da importância da Conquista que nos possibilita ir além da periodização proposta tanto por Foucault quanto por Agamben na análise da experimentação biopolítica do poder e do racismo e nos permite localizar, por exemplo, já no navio negreiro essa nova organização dos mecanismos de poder de que falam os autores. Não é possível falar sobre biopolítica sem falar de escravidão, ou antes, é necessário compreender o navio negreiro, a plantantion, a cidade escrava etc. como espaços de experimentação da vida pelo poder.

\section{Uma hipótese colonial: a racialização dos sis- temas penais. Raça, dispositivo, biopoder e poder punitivo}

A expressão racialização do sistema penal é, por óbvio, derivada da palavra raça. Ela indica, num sentido restrito (descritivo), a seletividade preferencial do sistema

nica da Índia poderia ter sido abandonada à temeridade dos 'infratores da lei na Índia' (Burke), sem que isso alterasse o clima político de toda uma época". Cf.: ARENDT, Hannah. Origens do totalitarismo. Trad. Roberto Raposo. São Paulo: Companhia das Letras, 2012. p. 215. penal sobre indivíduos pertencentes a determinados grupos raciais sobre os quais pesa o estigma da inferioridade. Logo, indica uma forma de discriminação. Nesse sentido (fraco), a racialização é apenas um conceito subsidiário das ideias de seletividade e vulnerabilidade que conhecemos $^{139}$. Pode indicar o aumento da seletividade racista de um sistema penal ou a improvável transformação de sistemas penais "igualitários" do ponto de vista racial em sistemas penais mais seletivos do ponto de vista dos marcadores raciais. ${ }^{140}$

Todavia, numa perspectiva mais ampla (compreensiva), a racialização apresenta um modo de ser de um grupo de sistema penais ocidentais, ou seja, indica a forma como sistemas penais foram historicamente concebidos como "reguladores" e constituidores das "diferenças raciais". Esse segundo sentido, capaz de subverter um pouco as relações entre raça e sistema penal, é o quebra-cabeça que poderia ser desmontado a partir de pesquisas que considerassem a hipótese colonial. Neste caso, a racialização representa a consciência progressiva dos atores sociais dos vínculos genéticos da violência institucional com a violência racista. $\mathrm{E}$, especialmente, indica o modo como o sistema penal comporia as engrenagens de um modelo social que produz e reproduz a raça. O sistema penal não apenas incide sobre a raça como algo que lhe é externo, mas integra um conjunto de fenômenos vinculados à Modernidade em que raça e sistema penal se constituem, ou ainda, de fenômenos dispostos num contínuo de construção social.

Todavia, a compreensão dessa segunda perspectiva pressupõe reconhecer que as explicações que se valem de expressões como raça e racismo, infelizmente, estão marcadas por alguns problemas iniciais.

Predomina, em diversos matizes, o cientificis-

139 ZAFFARONI, Eugenio Raúl et al. Direito penal brasileiro: teoria geral do direito penal. Rio de Janeiro: Revan, 2011; DUARTE, Evandro C. Piza; ZACKSESZKI. Sociologia dos sistemas penais: controle social, conceitos fundamentais e características. Publicações da Escola da AGU: direito constitucional e biopolítica - Escola da Advocacia-Geral da União Ministro Victor Nunes Leal. Brasília, ano 4, n. 17, abr. 2012

140 Não negamos o caráter produtivo de pesquisas que estão situadas no primeiro sentido. Aliás, elas são uteis para contextualizar os delineamentos da hipótese que propomos. Todavia, elas representam aquilo que, em outro contexto, Alessandro Baratta chamou de "teorias de médio alcance". Cf.: BARATTA, Alessandro. Criminologia crítica e crítica do direito penal: introdução à sociologia do direito penal. Rio de Janeiro: Revan, 1999. 
mo positivista como teoria e como "ethos intelectual". Ele impõe a redução da complexidade do social a partir da linguagem e projeta nesse reducionismo a essência da compreensão dos fenômenos. O "social” deveria ser discernido e separado, para ser testado, assim como são testados os fenômenos físicos. Daí a necessidade de produzir um refinamento da linguagem, separar os "objetos" do "real" para, depois, reuni-los num "quebra-cabeça" explicativo que, quase sempre, repete os pressupostos do "marco-teórico". Na forma de separar ou de segregar os objetos a partir dos conceitos todas as etapas posteriores já estão pressupostas. É essa operação que, literalmente, transformará o "fato" em seu "destino". As tentativas de compreender dimensões ideológicas no conhecimento naufragam quando o problema ideológico é posto a posteriori à aceitação desses artefatos do pensamento que separa a epiderme do corpo, a palavra do sujeito, o cultural do material etc.

Nesse contexto, há uma tradição acadêmica hegemônica que sobrevive no dualismo que separa discurso e real e que intenta colocar a raça como "mero" fenômeno ideológico. Logo, o "real” seria a escravidão e o "ideológico" (secundário) seria o racismo; ou o "real" seriam as "relações de classe" e "ideológico" (secundário) seria o racismo; ou o "real" seria "a pobreza" e o "racismo" apenas uma ilusão do agressor ou da vítima. Esse dualismo supõe, quase sempre, que o racismo é fruto de uma ideia nascida especialmente entre os "homens de ciência" em fins do século XVIII, que o racismo foi um "erro científico" ou o "erro de uma época" já superada por novos conhecimentos e foi utilizado de forma perversa por interesses variados (escravistas, classe dominante, agressor etc.) ou um "erro do olhar" inerente aos processos psíquicos de indivíduos e culturas sobre a diversidade do mundo situado fora de seu conhecimento anterior. Nessa tradição, há pouco espaço para pensar na materialidade de determinadas práticas sociais que também são discursos. ${ }^{141}$

De diferentes modos, a atual cartografia dos con-

141 Esses dualismos dizem respeito também ao protagonismo social, pois como afirmou Judith Butler em contexto semelhante: "En realidad, el resurgimiento extemporáneo de esta distinción favorece una táctica que aspira a identificar a los nuevos movimientos sociales con lo meramente cultural, y lo cultural con lo derivado y secundario, enarbolando en este proceso un materialismo anacrónico como estandarte de una nueva ortodoxia". Cf.: BUTLER, Judith. El marxismo y lo meramente cultural. New Left Review, Madrid, n. 2, p. 109-121, May-June, 2000. p. 109-121. ceitos e a tradição hegemônica que separa o "ideal" do que pode ser considerado "real" convergem para a conclusão de que o racismo é, em essência um "erro" moral, e, especialmente algo que mora "nos corações impuros" que podem ser "purificados" pelo entendimento (educação), pelo fim das relações econômicas de dominação (revolução) ou pela expiação decorrente da pena (punição). Como afirma Lawrence Lengbeyer: "O “coração" de alguém é puro em sua essência, ou não é - neste último caso, a pessoa é muito racista, um pouco racista ou algo entre esses dois extremos. O fator decisivo é seu sistema de crenças" ${ }^{142}$. Logo, a ciência retiraria o véu da ignorância, a educação seria a cura, a revolução de classes findaria o erro burguês, a religião cristã instauraria a irmandade universal, o direito moderno proibiria a distinção e instauraria a igualdade formal etc. Todavia, pouco se fala sobre a natureza dessa crença e do porque e como ela é tão persistente a argumentos racionais ou como ele se situa em práticas tão poucos elaboradas discursivamente como o medo.

Numa síntese apertada, é indispensável afastar algumas dessas percepções:

Em primeiro lugar, a politização da palavra raça e a insurgência dos racializados produziu uma transformação das palavras raça e racismo. Até os ano de 1930, o termo racismo era identificado com a doutrina sobre as raças, ou algo semelhante como o conjunto de ideias sobre a eugenia ${ }^{143}$. Todavia, passou a significar, após a Segunda Guerra Mundial, uma prática moralmente condenável, ou seja, o oposto do que pretendia. E, especialmente, foi reconstruída com novos conteúdos para explicitar as práticas de discriminação e os processos de subalternização de determinados grupos sociais. Desde então, o fenômeno racismo, colocado ao lado de palavras como preconceito, discriminação, segregação etc. tem sido identificado, nesse sentido, como algo mais intenso que o preconceito pois envolve relações de poder consolidadas em determinadas sociedades. A viragem no uso da palavra tem sido atribuída ao debate sobre o genocídio dos “judeus" no holocausto, sobretudo em razão das consequências práticas atribuídas à ideias sobre as raças

142 LENGBEYER, Lawrence A. Racismo e corações impuros. In: LEVINE, Michael P.; PATAKI, Tamas (Org.). Racismo em mente. São Paulo: Madras, 2005. p. 179-202.

143 THOMAS, Laurence. Igualdade invertida: uma resposta ao pensamento kantiano. In: LEVINE, Michael P.; PATAKI, Tamas (Org.). Racismo em mente. São Paulo: Madras, 2005. 
defendidas pelo nazismo. $\mathrm{O}$ uso do racismo no contexto interno europeu contribuiu para sua deslegitimação. Porém, a mudança paradigmática foi primeiro externa ao campo científico e foi capitaneada anteriormente pelos intelectuais afro-americanos, pelos movimentos por direitos civis e pelas guerras de libertação africana.

O termo racismo, assim como tantos outros, é hoje um espaço de disputa por significados. Há uma tentativa de reduzi-lo a noções legais, quer do sistema jurídico interno ou internacional. Todavia, seu significado sociológico transborda esses limites. Neste caso, há diversas tentativas de desacoplar o termo do contexto de seu surgimento, ou seja, das disputas empreendidas pelos povos subalternizados pelo "Ocidente", generalizando o seu uso para outras formas de assujeitamento. Entretanto, tal opção oculta a profunda proximidades entre os "processos de racialização" de negros, indígenas e judeus, bem como o intercâmbio de discursos. Assim, por exemplo, no discurso nazista o judeu aparece como "algo pior que um negro". A teoria nazista alemã não pode ser compreendida sem o conhecimento da influência das teorias sobre as raças e a eugenia no contexto norte-americano, as quais tinham como foco a defesa da inferioridades dos negros.

O termo racismo não pode ser reduzido às concepções cientificas sobre as raças que foram desenvolvidas a partir da segunda metade do XVIII e ao longo do século XIX. O racismo, antes da ciência, era constitutivo da percepção do homem moderno ocidental. Sua origem mais provável está na criação de relações de ordem prática instauradas no curso do colonialismo. Trata-se de um componente da subjetivação moderna, não de um mero "desvio". Ele define a condição humana e a humanidade do humanismo ocidental.

O racismo estrutura-se na separação entre mundo da cultura e natureza, atribuindo ao outro a permanência no lado natural da fronteira, onde ao mesmo tempo vive o incontrolável por forças ocultas e o controlável pelo conhecimento. Sob o ponto de vista ideológico, representa a inversão que oculta o retrocesso do processo civilizatório europeu quando ele se degenera em práticas de dominação no colonialismo. Na medida em que o colonialismo afasta o homem europeu do mundo da cultura, reduzindo-o a comportamentos voltados à exploração máxima de seus semelhantes, a cultura europeia tende a projetar nos povos não europeus as marcas que caracterizam a sua própria degradação, sua animalidade, sua ferocidade, seu canibalismo. O que se oculta no racismo não é a escravidão, mas a barbárie contida na narrativa sobre uma suposta identidade da civilização ocidental. Ou seja, o racismo, atribuindo aos subordinados a culpa pelo seu destino, oculta a degradação moral do Ocidente marcado pela barbárie que o constitui como processo civilizatório fundado na supremacia de técnicas e discursos para produzir a morte humana ${ }^{144}$. Nesse contexto, o comportamento mais comum provocado pelo racismo não é o ódio individual, mas o desprezo coletivo, ou seja, a indiferença moral diante da voz do "outro", considerado como meio, coisa, paisagem, natureza, animal, inferior, vivente matável, mas jamais um fim em si mesmo.

O "processo de racialização" não se resume a um ato de nomeação do "outro" ou do uso da palavra raça num "novo sentido". Muito embora o conteúdo das "crenças" racistas, presentes nas ofensas cotidianas ou nos teóricos racistas, revelem muito do que é a raça, não é a "representação" sobre o Outro que constitui relações racistas. Essas crenças produzem um reenvio continuo à natureza, falam de uma essencialização a partir do corpo. Apresentam no plano discursivo uma biologização do humano. Porém, essa biologização também é uma prática social não discursiva. Ela está presente na morte massificada das mães negras nos hospitais, no olhar de suspeição do segurança privado, na porta dos fundos das empregadas domésticas, nos homicídios das polícias urbanas, na proibição da festa no bairro, no toque de recolher etc.

O termo racismo pode servir para nominar o processo de redução do humano ou de sociedades humanas à condição de viventes ou os mecanismos de subjetivação a partir do corpo daqueles que são agenciados como pertencentes a uma coletividade de membros supostamente semelhantes, identificados mas privados de uma identidade individual ou coletiva insurgentes. Porém, de modos distintos, a racialização não atinge apenas o corpo dos racializados como subalternizados, mas os corpos nas sociedades ocidentais, regulando e distribuindo os modos de se habitar um corpo, sentir-se adequado, sofrer e ter prazer com este corpo, narrar-se como uma continuidade biológica (a família, os antepassados, a origem etc.). Nesse sentido, não apenas "negros" e "indígenas" foram racializados enquanto os demais grupos não teriam sido objeto de práticas racializadoras. A branquidade é também um modo de subjetivação do corpo, de sentir

144 MBEMBE, Achille. Necropolítica: traversées, diasporas, modernités. Raisons Politiques, Paris, n. 21, p. 29-60, 2006. Presses de Sciences Po. Editorial Melusina, S. L., 2011. 
com sua presença biológica. O racismo, como teoria racial, foi pensado em hierarquias internas ao grupo racial e externas em relação ao demais grupos.

A raça, quando não politizada pela voz e pelos corpos dos subalternizados, tende a produzir a subalternidade a partir do corpo e constituir-se também numa ofensiva contra as formas de corporeidade não adequadas à produção. Os processos de racialização ora negaram, por exemplo, as crenças religiosas "bárbaras" porque inadequadas à produção nos engenhos, ora aceitaram essas crenças para incentivar os conflitos entre grupos subalternos. A disposição do corpo era, portanto, percebida a partir de sua utilidade para o sistema produtivo e sua reprodução.De igual modo, desde os primeiros escritos ocidentais a raça está sexualizada ou diferenciada em termos de categorias sexuais. As aptidões para a reprodução e a beleza dos corpos "femininos" surgem como uma parte decisiva do discurso. A racialização atingiu primeiramente os subalternizados como mulheres, jovens e crianças, grupos vencidos e submetidos a formas tradicionais de escravidão. A racialização é, desde sua gênese, também um problema de gênero. Esse último aspecto aponta para outro aspecto. $\mathrm{O}$ racismo não pode ser identificado apenas como um modo de matar, pois é antes um modo de transformar vivos em viventes (redução biológica) e gerenciar suas forças, sua vitalidade. Vincula-se à reprodução em sentido amplo. Portanto, a morte física compõe o cálculo sistemático, mas não é a essência dessa prática. Nesse caso, é necessário fazer a distinção entre morte do "eu”, individual ou coletivo, e a condição de vivente. O racismo produz sempre, em arranjos distintos, a condição de vivente.

Malgrado esses pontos acima tratarem apenas superficialmente da necessidade de refletir sobre as categorias utilizadas para pensar a raça e o racismo, eles apontam para a ruptura do dualismo descritivo. Isso porque, como já se afirmou, antes de ser uma ideologia científica, a raça foi uma práxis do cotidiano; antes de ser um empreendimento do Estado-Nação, ela foi um empreendimento experimental e governada pelas forças do mercado; antes da palavra raça ser "inventada” pela ciência, ela era um artefato da vida social e do exercício do poder.

Os problemas apontados por esse dualismo e a síntese inicial dos argumentos podem ser organizados a partir de outras categorias para pensar o fenômeno do racismo, especialmente aquelas derivadas do debate sobre a condição histórica da humanidade. Somente na histori- cidade a raça pode ser compreende. De fato, a raça como teoria transhistórica é uma categoria do racismo presente nos discursos sobre as civilizações. A propósito, recentemente, Giorgio Agamben, ao investigar o pensamento de Michel Foucault, foi capaz de demonstrar a importância do conceito de "dispositivo" para a ruptura epistemológica empreendida pelas investigações desse autor:

Se "positividade" é o nome que, segundo Hyppolite, o jovem Hegel da ao elemento histórico, com toda a sua carga de regras, ritos e instituições impostas aos indivíduos por um poder externo, mas que se torna, por assim dizer, interiorizada nos sistemas das crenças e dos sentimentos, então Foucault, tomando emprestado este termo (que se tornara mais tarde "dispositivo") toma posição em relação a um problema decisivo, que é também o seu problema mais próprio: a relação entre os indivíduos como seres viventes e a elemento hist6rico, entendendo com este termo a conjunto das instituições, dos processos de subjetivação e das regras em que se concretizam as relações de poder. O objetivo último de Foucault não é, porém, como em Hegel, aquele de reconciliar as dois elementos. E nem mesmo a de enfatizar a conflito entre estes. Trata-se para ele antes de investigar as modos concretos em que as positividades (ou os dispositivos) atuam nas relações, nos mecanismos e nos "jogos" de poder ${ }^{145}$.

O conceito permearia a obra de Michel Foucault e se situaria para além daquilo que foi investigado, constituindo um modo de empreender a pesquisa que poderia ser utilizado em outros contextos. O uso foucaultiano teria apreendido as três acepções da expressão dispositivo encontradas no dicionário: a jurídica - a parte da sentença (ou de uma lei) que decide e dispõe; a tecnológica - a maneira pela qual são dispostas as peças de uma máquina, e, por extensão a própria máquina; a militar - o conjunto de meios (recursos) dispostos conforme um plano. Ou seja, o uso da língua teria fragmentado aquilo que uma origem comum e o próprio Michel Foucault mostravam conexos. Ao usar a expressão dispositivo, ele teria tratado de se referir a "uma serie de praticas e de mecanismos (ao mesmo tempo linguísticos e não linguísticos, jurídicos, técnicos e militares) com ao objetivo de fazer frente a uma urgência e de obter um efeito."

Em outras palavras, Michel Foucault reunia, ao invés de dividir, pois a multiplicidade também poderia propor a construção de dimensões daquilo que se inves-

145 AGAMBEN, Giorgio. O que é o contemporâneo? e outros ensaios. Trad. Vinícius Nicastro Nonesko. Chapecó: Argos, 2009. p. 32-33. 
tigava (a ciência, a punição, a sexualidade etc.). De fato, segundo Giorgio Agamben, a noção de dispositivo pode ser resumida a partir de três pontos:

a. É um conjunto heterogêneo, linguístico e não-linguístico, que inclui virtualmente qualquer coisa no mesmo título: discursos, instituições, edifícios, leis, medidas de polícia, proposições filosóficas etc. O dispositivo em si mesmo é a rede que se estabelece entre esses elementos. b. O dispositivo tem sempre uma função estratégica concreta e se inscreve sempre numa relação de poder. c. Como tal, resulta do cruzamento de relações de poder e de relações de saber ${ }^{146}$.

Enfim, três questões centrais podem ser compreendidas a partir dessa perspectiva. Primeiro, ela propõe uma alternativa entre racismo como práxis e como episteme, pensando-se a Conquista, o genocídio indígena e africano, a escravidão etc. como práxis constitutivas, mesmo antes do surgimento do signo "raça". Segundo, a raça não precisa ter um "referente material" (na economia ou na classe social) para ser compreensível. Sua compreensão se dá na historicidade, na contingência da formação da Modernidade. No limite, a raça constitui-se a partir de funções estratégicas concretas, relacionadas às insurgências e às subalternidades na Modernidade. Terceiro, permite compreender que a raça e a punição constituem a mesma "rede" de práticas e significados.

Ao invés da separação de duas categorias (raça e punição) sugere-se, portanto, que elas existem num contínuo de "mecanismos" e "jogos de poder". O racismo é um "modo de ser" de um grupo de sistema penais ocidentais, ou seja, identifica a forma como sistemas penais ocidentais foram historicamente concebidos como "constituidores" e "reguladores" das "diferenças raciais", formado por práticas, instituições e táticas. Ou seja, a racialização dos sistemas punitivos não é um evento pontual, mas o processo de constituição da categoria raça. Não poderia ter existido a construção negativa da raça sem sistema penal, e não se pode compreender o sistema penal sem a construção da relações raciais. ${ }^{147}$

146 AGAMBEN, Giorgio. O que é o contemporâneo? e outros ensaios. Trad. Vinícius Nicastro Nonesko. Chapecó: Argos, 2009. p. 29.

147 De igual modo, não se pode desconsiderar o caráter constitutivo das relações de gênero dos espaços de suplício doméstico que se apresenta de modo semelhante, numa relação de complementariedade. Ou, ainda, da "anormalidade", terreno onde tradicionalmente se situou a crítica foucautiana com a compreensão do encarceramento da loucura, e para onde conduzem novas pesquisas sobre a sexualidade (encarceramento e estigmatização dos homossexuais). Sobre o tema, cf.: CARVALHO, Salo. Sobre
A ideia e a prática da "raça" (no sentido do racismo) dependeu sempre da segregação espacial proporcionada por sistemas punitivos. As sociedades ocidentais, nas quais o problema do racismo é persistente, constituíram e reconstituíram a identidade negativa das raças pela punição. Ou seja, forjaram valores sociais cujo cerne é identificar sem permitir uma identidade. Assim, determinados grupos humanos foram unificados num destino comum (o colonialismo, o imperialismo ou o neoliberalismo), bem como incluídos numa comunidade de vítimas reais ou potenciais da violência institucional dos sistemas punitivos, mas, ao mesmo tempo, eles foram proibidos de fazer acordos mediante processos de comunicação transversais. Os sistemas penais serviram para demarcar o início e o fim da identidade racial moderna, criando a proibição de coalizão entre todos os excluídos. Eles foram, ainda, idealizados ou construídos como mecanismos de defesa da civilização ocidental contra os processos civilizatórios desencadeados por outros contingentes populacionais.

Porém, o mais essencial é que na escravidão punitiva, nas práticas penais, na escravização e na racialização punitiva busca-se sempre a constituição "dos sujeitos", como vida nua ou como viventes ${ }^{148}$. O racismo científico constitui-se a partir dessa redução ao biológico capaz de se propor o empreendimento (sempre frustrado, mas sempre atualizado) que pretendeu a separação das vozes, da ações e das memórias em relação às forças corporais destinadas à produção e aos corpos demarcados que poderiam servir ao desejo do outro. Os povos originários das Américas e da Diáspora Africana são, de fato, o protótipo em larga escala do homo saccer. Nascem quando sociedades inteiras foram pensadas como vida nua, biologia e geografia, população e território, espaço aberto, "liberdade" de alguém sobre "algo".

Desse ponto de vista, dizer que o sistema penal é racista não necessita de um complemento para dar um sentido a essa afirmação, acoplando-a à ideia de classe social ou à noção de dimensão simbólica do capitalismo.

a criminalização da homofobia: perspectivas desde a criminologia queer. Revista Brasileira de Ciências Criminais, São Paulo, v. 99, p. 187-211, 2012a. CARVALHO, Salo. Sobre as possibilidades de uma criminologia queer. Sistema Penal \& Violência (Online), v. 4, p. 152-168, 2012b.

148 AGAMBEN, Giorgio. Homo sacer: o poder soberano e a vida nua I. Trad. Henrique Burigo. Belo Horizonte: UFMG, 2010; AGAMBEN, Giorgio. O que resta de Auschwitz: o arquivo e a testemunha (Homo Sacer III). Trad. Selvino J. Assmann. São Paulo: Boitempo, 2008. 
A racialização dos sistemas penais ocorreu na história. A historicidade, não a mera artificialidade do conceito vinculada a uma mecânica social descrita na teoria social, é que lhe confere uma possibilidade de compreensão. Tampouco há necessidade de se recorrer a uma concepção problemática de "luta entre raças", essencialmente racista.

O sistema penal representa o ponto de gravidade que estabiliza sentidos sobre o ser negro no projeto colonial da Modernidade. Sim, o racismo estrutura as estruturas repressivas no Brasil, mas não é só isso. Não é o efeito inesperado dessas práticas, mas o principal efeito perseguido por essas instituições. Não é tampouco apenas a repressão ao negro, como categoria externa. Aqui raça e punição se encontram numa simbiose em que a racialização é produzida pelo sistema penal e o sistema penal não pode operar uma renúncia à racialização. A culpa atribuída aos negros para sua escravização, a condição de vida nua das práticas de repressão aos insurgentes à subordinação, a tentativa de redução constante ao biológico e a expropriação coletiva de saberes etc. reproduzem-se de novos modos na negação da dignidade humana pelas diversas estratégias de controle social.

A justificativa para a escravidão fazia referência à existência de uma falha moral decorrente de um pecado natural. Os negros carregavam contra si as marcas de Cam. O escravo era escravo porque seu grupo de origem havia pecado. A própria escravidão, na versão do Padre Antônio Vieira, era um modo de purgar essa mancha. Quando Frantz Fanon escreveu "Les Damnées de la Ter$r e$ ", rapidamente traduzido para "Os Condenados da Terra”, algo se perdeu na tradução que remetia àquele sentido primeiro da danação intrínseca daqueles que nasciam negros. Nunca foram "condenados" por um tribunal, mas eram "danados" por serem negros, por sua biologia, e, por conta disso, conduzidos a tribunais.

Por fim, malgrado uma ampla produção teórica sobre racismo no Brasil das últimas décadas, contra toda evidência e todas as vozes das vítimas que se levantam contra seus agressores, há uma reorganização estrutural da branquidade na academia brasileira. Além das dificuldades de reconhecimento enfrentadas por grupos excluídos, sempre que se apresenta um discurso que denuncia o racismo, intenta-se demarcar distinções "locais", capazes de impedir ou dificultar a compreensão dessa importância. A estratégia discursiva consiste em, ao se demarcar uma diferença "nacional", afastar a apropriação tanto de perspectivas brasileiras quanto estrangeiras que consi- derem o racismo como elemento estrutural das práticas e discursos no país. O raciocínio não é novo - a abolição foi retardada no Brasil sob o fundamento de que a escravidão aqui era diferente. As "diferenças nacionais" são, de fato, resultado de um longo processo histórico em que o medo da presença do "outro", no espaço da política e do direito, produziu uma tradição acadêmica capaz de negar uma memória coletiva de lutas sociais. Insistimos, porém, com a hipótese de que a ideia e a prática da "raça" organizam os lugares de exclusão e o controle social. Nomear o racismo nas práticas de controle social não é criar o racismo onde não há, ao invés disso, é descumprir o pacto da branquidade que consiste em silenciar as vozes negras $^{149}$.

A propósito, retornando a Agamben, até agora falamos de duas duas grandes classes, os seres viventes (ou as substancias) e os dispositivos. Porém, "entre os dois, como terceiro, há os sujeitos". "Chamo sujeito o que resulta da relação e, por assim dizer, do corpo-a-corpo entre os viventes e os dispositivos." ${ }^{150}$. Nesse caso, o sujeito não é apenas a subjetivação do poder, mas as inúmeras contradições desse processo e, especialmente, seu caráter fragmentado, discursivo e reflexivo. Na perspectiva de Judith Butler, cremos ser possível pensar a responsabilidade ética de um sujeito "cujas condições de surgimento jamais poderão ser totalmente explicadas"151. Nessa perspectiva, abrem-se múltiplos caminhos, na perspectiva na qual escrevemos. Negar-se, no limite, à condição de reprodução das dimensões do dispositivo que funda o racismo. O que implica em não validar estratégias de assujeitamento, especialmente em relação aos discursos. Insistir numa estratégia de profanação da "raça". No sentido de "profanação" proposto por Agamben. O que implica em reconhecer que a "raça" tem sido "profanada" desde o principio pelos sujeitos submetidos a esse dispositivo. Profanar, nesse caso, é vivenciar no plano da política e do direito, a partir daqueles que foram "racializados", as narrativas e agenciamentos contra os efeitos e as estraté-

149 DUARTE, Evandro C. Do medo da diferença à igualdade como liberdade: as ações afirmativas para negros no ensino superior e os procedimentos de identificação de seus beneficiários. 2011. Tese (Doutorado) - Universidade de Brasília, Brasília, 2011.

150 AGAMBEN, Giorgio. O que é o contemporâneo? e outros ensaios. Trad. Vinícius Nicastro Nonesko. Chapecó: Argos, 2009. p. 41.

151 BUTLER, Judith. Relatar a si mesmo. Crítica da violência ética. Tradução Rogério Bettoni, Prefácio Vladimir Safatle. Belo Horizonte: Autêntica, 2015. 
gias do próprio poder. E, de modo bem direto, pensar a raça não a partir de uma teoria das raças, mas de teorias sobre o racismo. Pensar em teorias sobre o racismo que considerem os sujeitos racializados como produtores de sua auto-compreensão e transformação.

\section{Referências}

ADORNO, Sérgio. Discriminação racial e justiça criminal. Novos Estudos, São Paulo, n. 43, p. 45-63, nov. 1995.

AGAMBEN, G. Homo Sacer: o poder soberano e a vida nua I. Trad. Henrique Burigo. Belo Horizonte: UFMG, 2010.

AGAMBEN, G. O que é o contemporâneo?: e outros ensaios. Trad. Vinícius Nicastro Nonesko. Chapecó: Argos, 2009.

AGAMBEN, G. O que resta de Auschwitz: o arquivo e a testemunha (Homo Sacer III). Trad. Selvino J. Assmann. São Paulo: Boitempo, 2008.

ALCOFF, Linda Martín. Uma epistemologia para a próxima revolução. Revista Sociedade e Estado, Brasília, v. 31, n. 1, p. 129-143, jan./abr. 2016.

ALENCASTRO, Luiz Felipe de. O trato dos viventes: formação do Brasil no Atlântico Sul. São Paulo: Cia. das Letras, 2000.

ANDRADE, Vera Regina Pereira de. Criminologia e feminismo: da mulher como vítima à mulher como sujeito de construção da cidade. Sequência, Florianópolis, v. 35, p. 42-49, p. 1997

ANDRADE, Vera Regina Pereira de. Do paradigma etiológico ao paradigma da reação social: mudança e permanência de paradigmas criminológicos na ciência e no senso comum. Revista Brasileira de Ciências Criminais, São Paulo, n. 14, p. 276-287, abr./jun. 1996.

ANDRADE, Vera Regina Pereira de. A ilusão de segurança jurídica: do controle da violência à violência do controle penal. Porto Alegre: Livraria do Advogado, 2003.

ANDRADE, Vera Regina Pereira de. Dogmática e sistema penal: em busca da segurança jurídica prometida. 1994. Dissertação (Mestrado em Direito) - Centro de Ciências Jurídicas, Universidade Federal de Santa Catarina, Florianópolis, 1994.

ARENDT, Hannah. Origens do totalitarismo. Trad. Roberto Raposo. São Paulo: Companhia das Letras, 2012.

ARGUELLO, Katie Silene Cáceres. O Ícaro da moderndiade: direito e política em Max Weber. São Paulo: Acadêmica, 1997.

BANTON, Michael. A idéia de raça. São Paulo: M. Fontes, 1991.
BARATTA, Alessandro. Criminologia crítica e crítica do direito penal: introdução à sociologia do direito penal. Rio de Janeiro: Revan, 1999.

BARCELLONA, Pietro. O egoísmo maduro e a insensatez do capital. São Paulo: Ícone, 1995.

BARROS, José D’Assunção. A construção social da cor. Petrópolis: Vozes, 2009.

BATISTA, Malaguti Vera. O medo na cidade do Rio de Janeiro: dois tempos de uma história. Rio de Janeiro: Revan, 2003.

BENJAMIN, Walter. Sobre o conceito da história. In: BENJAMIN, Walter. O anjo da história. Belo Horizonte: Autêntica, 2013. p. 07-20.

BENJAMIN, Walter. Crítica da violência: crítica do poder. Revista Espaço Acadêmico, Maringá, ano 2, n. 21, fev. 2003.

BERNARDINO-COSTA, Joaze. Saberes subalternos e decolonialidade: os sindicatos das trabalhadoras domésticas no Brasil. Brasília: Universidade de Brasília, 2015.

BERNARDINO-COSTA, Joaze; GROSFOGUEL, Ramón. Decolonialidade e perspectiva negra. Sociedade e Estado, Brasília, v. 31, p. 15-24, 2016.

BUCK-MORSS, Susan. Hegel e Haiti. Trad. Sebastião Nascimento. Novos Estudos, São Paulo, v. 90, p. 131-171, 2011.

BUCK-MORSS, Susan. Hegel, Haiti, and universal history. Pitssburgh: University of Pitssburgh Press, 2009.

BUTLER, Judith. El marxismo y lo meramente cultural. New Left Review, Madrid, n. 2, p. 109-121, May/June, 2000.

BUTLER, Judith. Relatar a si mesmo: crítica da violência ética. Tradução Rogério Bettoni, Prefácio Vladimir Safatle. Belo Horizonte: Autêntica, 2015.

CAMPOS, Carmen Hein de Campos. Teoria crítica feminista e crítica às criminologias: estudo para uma perspectiva feminista em criminologia no Brasil. 2013. Tese (Doutorado) - Ciências Criminais pela Pontifícia Universidade Católica do Rio Grande do Sul, Rio Grande do Sul, 2013.

CARDOSO, Lourenço. A branquitude acrítica revisitada e a branquidade. Revista da $A B P N$, Florianópolis, v. 6, n. 13, p. 88-106, mar./jun. 2014.

CARVALHO, Salo. Sobre a criminalização da homofobia: perspectivas desde a criminologia queer. Revista Brasileira de Ciências Criminais, São Paulo, v. 99, p. 187-211, 2012a.

CARVALHO, Salo. Sobre as possibilidades de uma criminologia queer. Sistema Penal \& Violência (Online), v. 4, p. 152-168, 2012b. 
COHEN, Stanley. Modelos ocidentales utilizados en el tercer mundo para el control del delito: benignos o malignos? Cenipec, Merida, Venezuela, n. 6, p. 63-110, 1984.

COHEN, Stanley. Vísiones del control social. Trad. Elena Larrauri. Barcelona: PPU, 1988.

COLLINS, Patricia Hill. Black feminist thought: knowledge, consciousness, and the politics of empowerment. Nova York: Routledge, 2009.

CONNEL, Raewyn. A iminente revolução na teoria social. Revista Brasileira de Ciências Sociais, São Paulo, v. 27. n. 80, p. 09-20, out. 2012.

COSTA, Pedro Henrique Argolo. Entre hidra e leviatã: o nomos da terra de Carl Schmitt e o paradoxo da história universal. 2016. TCC (Monografia em Direito) - Universidade de Brasília, Brasília, 2015.

CRENSHAW, Kimberlé et al. (Ed). Critical race theory. Nova York: The New Press, 1995.

DERRIDA, Jacques. Força de lei: o fundamento místico da autoridade. Trad. Leyla Perrone-Moisés. São Paulo: M. Fontes, 2010.

DUARTE, Evandro C. Do medo da diferença à igualdade como liberdade: as ações afirmativas para negros no ensino superior e os procedimentos de identificação de seus beneficiários. 2011. Tese (Doutorado) - Universidade de Brasília, Brasília, 2011.

DUARTE, Evandro C. Piza. Criminologia \& racismo. Curitiba: Juruá, 2002.

DUARTE, Evandro C. Piza; QUEIROZ, Marcos V. Lustosa. A Revolução Haitiana e o Atlântico Negro: o constitucionalismo em face do lado oculto da modernidade. Brasília, 2016 (no prelo).

DUARTE, Evandro C. Piza; ZACKSESZKI. Sociologia dos sistemas penais: controle social, conceitos fundamentais e características. Publicações da Escola da AGU: direito constitucional e biopolítica - Escola da Advocacia-Geral da União Ministro Victor Nunes Leal. Brasília, ano 4, n. 17, abr. 2012.

DUBOIS, Laurent. Avengers of the new world: the story of the Haitian Revolution. Harvard: Harvard University Press, 2004.

DUBOIS, W. E. B. As almas da gente negra. Tradução, introdução e notas Heloísa Toller Gomes. Rio de Janeiro: Lacerda, 1999.

DUSSEL, Enrique. 1492: o encobrimento do outro: a origem do mito da modernidade: Conferências de Frankfurt. Trad. Jaime A. Clasen. Petrópolis: Vozes, 1993.
FANON, Frantz. Os condenados da terra. Trad. Enilce Albergaria Rocha, Lucy Magalhães. Juiz de Fora: UFJF, 2005.

FANON, Frantz. Pele negra, máscaras brancas. Trad. Renato da Silveira. Salvador: EdUFBA, 2008.

FARIA, Juliana Barreto et al. Cidades Negras: africanos, crioulos e espaços urbanos no Brasil escravista do século XIX. Rio de Janeiro: Alameda, 2006.

FICK, Carolyn. The making of Haiti: the Saint Domingue Revolution from below. USA: The University of Tennessee Press, 1990.

FISCHER, Sibylle. Constituciones haitianas: ideología y cultura posrevolucionarias. Casa de las Américas, La Habana, Cuba, n. 233, p. 18-31, oct./dic. 2003.

FISCHER, Sibylle. Modernity disavowed: Haiti and the cultures of slavery in the age of reveolution. USA: Duke University Press, 2004.

FLAUZINA, Ana Luiza Pinheiro. Corpo negro caído no chão: o sistema penal e o projeto genocida do Estado brasileiro. Rio de Janeiro: Contraponto, 2008.

FORMIGA, Glêides Simone de. A cor vigiada: uma crítica ao discurso racializado de prevenção ao crime. 2010. Dissertação (Mestrado em Antropologia Social) - Universidade de Brasília, Brasília, 2010.

FOUCAULT, Michel. Em defesa da sociedade. Trad: Maria Ermantina Galvão. São Paulo: M. Fontes, 1999.

FOUCAULT, Michel. Genealogía del racismo. Buenos Aires: Altamira, 1976.

FOUCAULT, Michel. Microfísica do poder. Trad. e org. de Roberto Machado. Rio de Janeiro: Graal, 1992.

FOUCAULT, Michel. Vigiar e punir: nascimento da prisão. Trad. Raquel Ramalhete. Petrópolis: Vozes, 2011.

FREITAS, Felipe da Silva. Novas perguntas para a criminologia brasileira: poder, racismo e direito no centro da roda. In: ENCONTRO DO GRUPO BRASILEIRO DE CRIMINOLOGIA CRÍTICA, 3., 2016, Salvador. Anais... Salvador, 2016.

GEGGUS, David P. Haitian revolutionary studies. USA: Indiana University Press, 2002.

GENOVESE, Eugene Dominick. Da rebelião à revolução: as revoltas de escravos negros nas Américas. São Paulo: Global, 1983.

GILROY, Paul. O Atlântico Negro. Trad. Cid Knipel Moreira. 2. ed. São Paulo: 34, 2012.

GOBINEAU, Arthur. Essai sur l'inégalité des races humaines. Paris: Pierre Belfond, 1967. 
GOMES, Flávio; SOARES, Carlos Eurgênio. Sedições, haitianismo e conexões no Brasil escravista: outras margens do Atlântico Negro. Novos Estudos, São Paulo, n. 63, p. 131-144, 2002.

GORENDER, Jacob. A escravidão reabilitada. São Paulo: Ática, 1990.

GREEME, Helen Taylor; GABBIDON, Shaun L. Race and crime: a text/reader. California: SAGE, 2012.

GUIMARÃES, Antonio Sérgio Alfredo. Combatendo o racismo: Brasil, África do Sul e Estados Unidos. Revista Brasileira de Ciências Sociais, São Paulo, v. 14, n. 39, fev. 1999.

GUIMARÃES, Johnatan Razen Ferreira. Coordenadas do possível: o lugar da violência e a legitimidade da ocupação de terras na ADI 2.213-0. 2015. Dissertação (Mestrado em Direito) - Universidade de Brasília, Brasília, 2015.

HALL, Stuart. Da diáspora: identidades e mediações culturais. Organização Liv Sovik; Tradução Adelaine La Guardia Resende. 2. ed. Belo Horizonte: UFMG, 2013.

HEGEL Georg Wilhelm Friedrich. Fenomenologia do espírito. Rio de Janeiro: Vozes, 2012.

JAMES. C. L. R. Os jacobinos negros: Toussaint L'Ouverture e a revolução de São Domingos. Tradução Afonso Teixeira Filho. São Paulo: Boitempo, 2007.

JARDIM, Drielly. MNU: 34 anos de luta contra o preconceito racial. Disponível em: <http://www.palmares.gov. br/?p=21311>. Acesso em: 05 nov. 2016.

KELLNER, Douglas. Habermas, the public sphere, and democracy: a critical intervention. In: HAHN, Lewis Edwin. Perspectives on Habermas. USA: Open Court, 2000. p. 259-287.

LENGBEYER, Lawrence A. Racismo e corações impuros. In: LEVINE, Michael P.; PATAKI, Tamas (Org.). Racismo em mente. São Paulo: Madras, 2005. p. 179-202.

LINEBAUGH, Peter; REDIKER, Marcus. A hidra de muitas cabeças: marinheiros, escravos, plebeus e a história oculta do Atlântico revolucionário. Trad. Berilo Vargas. São Paulo: Cia das Letras, 2008.

MATTEUCI, Nicola. Racismo. In: BOBBIO, Norberto; PASQUINO, Gianfranco; MATEUCCI, Nicola. Dicionário de política. Brasília: Universidade de Brasília, 1993. p. 1059-1062.

MATTOS, Márcio Júlio da Silva. Reconhecimento, identidade e trabalho sujo na PMDF. 2012. Dissertação (Mestrado em Sociologia) - Universidade de Brasília, Brasília, 2012.
MBEMBE, Achille. Necropolítica: traversées, diasporas, modernités. Raisons Politiques, Paris, n. 21, p. 29-60, 2006.

MENDES, Soraia da Rosa. Criminologia feminista: novos paradigmas. São Paulo: Saraiva, 2014.

MIGNOLO, Walter. Historias locales: diseños globales. Colonialidad, conocimientos subalternos y pensamiento fronterizo. Trad. Juan María Madariaga y Cristina Vega Solís. Madrid: Akal, 2003.

MUNANGA, Kabengele. Rediscutindo a mestiçagem. Belo Horizonte: Autêntica, 2004.

NADER, Gislene. Direito no Brasil: história e ideologia. In: LYRA, Doreodó Araújo (Org.). Desordem e processo. Porto Alegre: S. A. Fabris, 1986. p. 145-157.

NASCIMENTO, Abdias do; NASCIMENTO, Elisa Larkin. Reflexões sobre o movimento negro no Brasil, 1938-1997. In: HUNTLEY, Lynn; GUIMARÃES, Antônio Sérgio Alfredo. Tirando a máscara: ensaios sobre o racismo no Brasil. São Paulo: Paz e Terra, 2000. p. 203-235.

NASCIMENTO, Washington Santos. São Domingos, o grande São Domingos: repercussões e representações da Revolução Haitiana no Brasil escravista (1791-1840). Dimensões, Vitória, v. 21, p. 125-142, 2008.

OLMO, Rosa de. America Latina y su criminologia. México: Siglo Veintiuno, 1984.

OSÓRIO, Rafael Guerreiro. O sistema classificatório de "cor ou raça" do IBGE. In: BERNARDINO-COSTA; GALDINO, Daniela. Levando a raça a sério: ação afirmativa e universidade. Rio de Janeiro: DP\&A, 2004. p. 85-135.

PETRUCCELI, José Luis. A cor denominada: estudos sobre a classificação étnico-racial. Rio de Janeiro: DP\&A, 2007.

RAMOS, Silvia; MUSUMECI, Leonarda. Elemento suspeito: abordagem policial e discriminação na cidade do Rio de Janeiro. Rio de Janeiro: Civilização Brasileira, 2005.

RIBEIRO, Darcy. O processo civilizatório: estudos de antropologia e civilização; etapas da evolução sócio-cultural. Petrópolis: Vozes, 1987.

ROUSSEAU, Jean-Jacques. O contrato social: princípios do direito político. Trad: Antonio de Pádua Danesi. São Paulo: M. Fontes, 1996.

RUSCHE, Georg; KIRCHHEIMER, Otto. Punição e estrutura social. Rio de Janeiro: F. Bastos, 1999.

SAFATLE, Vladimir. Curso integral: A Fenomenologia do Espírito, de Hegel. Brasil, 2007. Disponível em: <https:// www.academia.edu/5857053/Curso_Integral_-_A_Fenomenologia_do_Esp\%C3\%ADrito_de_Hegel_2007_>. Acesso em: 05 nov. 2016. 
SCHMITT, Carl. O conceito do político/Teoria do Partisan. Trad. Geraldo de Carvalho. Belo Horizonte: Del Rey, 2008.

SEGATO, Rita Laura. La nación y sus otros: raza, etnicidad y diversidad religiosa en tiempos de política de la identidad. Buenos Aires: Prometeo Libros, 2007.

SILVA, Elton Batista da; SOARES, Ana Loryn. A Revolução do Haiti: estudo de um caso. Ameríndias, Fortaleza, ano 1, v. 1, p. 01-08, 2006.

SILVA, Gilvan Gomes da. A lógica da PMDF na construção do suspeito. 2009. Dissertação (Mestrado em Sociologia) Universidade de Brasília, Brasília, 2009.

SODRÉ, Muniz. O terreiro e a cidade: a forma social do negro-brasileiro. Petrópolis: Vozes, 1988.

STENOU, Katerina. Lutas contra a escravidão: Ano Internacional de luta contra a escravidão e de sua abolição 2004. Paris: UNESCO, 2004. Disponível em: <http://www. unesco.org/culture>. Acesso em: 05 nov. 2016.

THOMAS, Laurence. Igualdade invertida: uma resposta ao pensamento kantiano. In: LEVINE, Michael P.; PATAKI, Tamas (Org.). Racismo em mente. São Paulo: Madras, 2005. p. 250-269.

WACQUANT, Loïc. A cor da justiça: quando gueto e prisão se encontram e se mesclam. In: LINS, Daniel; WACQUANT, Loïc (Org.). Repensar os Estados Unidos. Campinas: Papirus, 2003. p. 159-208.

WACQUANT, Loïc. Crime e castigo nos Estados Unidos: de Nixon a Clinton. Revista de Sociologia e Política. Dossiê Cidadania e Violência. Curitiba, n. 13, p. 39-50, nov. 1999.

WACQUANT, Loïc. Da escravidão ao encarceramento em massa: repensando a "questão racial" nos Estados Unidos. In: SADER, Emir (Ed.). Contragolpes. São Paulo: Boitempo, 2006. p. 11-30.
WACQUANT, Loïc. Punir os pobres. Rio de Janeiro: Revan, 2007.

WACQUANT, Loïc. As prisões da miséria. Rio de Janeiro: J. Zahar, 2001.

WARE, Vron. Branquidade: identidade branca e multiculturalismo. Rio de Janeiro: Garamond, 2004.

ZAFFARONI, Eugenio Raúl et al. Direito penal brasileiro: teoria geral do direito penal. Rio de Janeiro: Revan, 2011.

ZAFFARONI, Eugenio Raúl. Criminología: aproximación desde un margen. Bogotá: Temis, 1993.

ZAFFARONI, Eugenio Raúl. Em busca das penas perdidas: a perda de legitimidade do sistema penal. Tradução de Vânia Romano Pedrosa e Amir Lopes da Conceição. Rio de Janeiro: Revan, 1991.

ZAFFARONI, Eugenio Raúl. Sistemas penales y derechos humanos en América Latina: primer informe. Buenos Aires: De Palma, 1984.

ZAFFARONI, Eugenio Raúl; PIERANGELI, José Henrique. Manual de direito penal brasileiro: parte geral. São Paulo: Revista dos Tribunais, 1997.

ZUBERI, Tukufu. Más espeso que la sangre: la mentira del análisis estadístico según teorías biológicas de la raza. Traducción de Pablo González: Thicker than blood. How racial statistics lie. Bogotá: Facultad de Ciencias Humanas, Centro de Estudios Sociales (CEs), Grupo de Investigación iDCARÁn, Universidad Nacional de Colombia, 2013.

ZUBERI, Tukufu; BONILLA-SILVA, Eduardo (Ed.). White logic, white methods: racism and methodology. Lanham: Plymouth, Rowman \& Littlefield Publishers, 2008. 